\title{
Achieving sustainable development in India along low-carbon pathways: Macroeconomic assessment
}

\author{
Dipti Gupta ${ }^{a^{*}}$, Frederic Ghersi ${ }^{b}$, Saritha S. Vishwanathan ${ }^{c}$, Amit Garg $^{d}$
}

apublic Systems Group, Indian Institute of Management, Ahmedabad, Dorm 34, Room 18, Vastrapur, Gujarat, India-380015. Email: diptig@iima.ac.in

${ }^{b}$ CIRED, AgroParisTech, CIRAD, CNRS, EHESS, Ecole des Ponts ParisTech, Univ Paris-Saclay. UMR 8568 CIRED, Campus du Jardin Tropical, 45 bis, avenue de la Belle Gabrielle, 94736 Nogent-sur-Marne, France.Email: ghersi@centre-cired.fr

'Faculty Room 12, Indian Institute of Management, Ahmedabad, Gujarat, India-380015. Email: sarithasv@iima.ac.in

${ }^{d}$ Wing 16, Public Systems Group, Indian Institute of Management, Ahmedabad, Gujarat, India380015. Email: amitgarg@iima.ac.in

\begin{abstract}
*Corresponding author: Dipti Gupta. Address: Dorm34, Room18, Public Systems Group, Indian Institute of Management, Ahmedabad, Gujarat, India- 380015. Phone: +917043021429. Email: diptig@iima.ac.in
\end{abstract}

\section{Abstract}

Achieving fast and inclusive economic growth concurrently with greenhouse gases (GHG) emission control could have wide-ranging implications for the Indian economy, predominantly fuelled by fossil energies. India faces high income inequality with the bottom $50 \%$ of its population owning only $2 \%$ 
of total national wealth. Other developmental challenges include 304 million people living in poverty, 269 million without access to electricity, 92 million without access to safe drinking water, and around 2 million homeless. Despite such challenges, India has committed to reduce the GHG emission intensity of its GDP 33\% to 35\% below its 2005 level by 2030 , including via turning $40 \%$ of its power-generation capacity away from fossil sources. To explore the macroeconomic consequences of achieving development along low-carbon pathways, we use a hybrid modelling architecture that combines the strengths of the AIM/Enduse bottom-up model of Indian energy systems and the IMACLIM top-down economy-wide model of India. This hybrid architecture stands upon an original dataset that reconciles national accounting, energy balance and energy price statistics. With this tool, we demonstrate that low-carbon scenarios can accommodate yearly economic growth of $5.8 \%$ from 2013 to 2050 i.e. perform close to if not slightly higher than our business-as-usual scenario, despite high investment costs. This result partly stems from improvement of the Indian trade balance via substantial reduction of large fossil fuel imports. Additionally, it is the consequence of significant shifts of sectoral activity and household consumption towards low-carbon products and services of higher value-added. These transitions would require policies to reconcile the conflicting interests of entrenched businesses in retreating sectors like coal and oil, and the emerging low-carbon sectors and technologies such as renewables, smart grids, electric vehicles, modern biomass energy, solar cooking, carbon capture and storage, etc.

\section{Keywords}

India; energy-economy modelling; low carbon pathways; $2^{\circ} \mathrm{C}$; sustainable development

\section{Highlights}

- High economic growth targets are compatible with low-carbon measures. 
- Investment growth towards low-carbon technologies is required.

- Rapidly growing industries require aggressive energy-efficiency and demand-reduction measures.

- Need to reconcile conflicting interests of retreating sectors and emerging low-carbon sectors. 


\section{Achieving sustainable development in India along low- carbon pathways: Macroeconomic assessment}

\section{Introduction}

The Developing Indian economy faces multiple challenges echoing key dimensions of the Sustainable Development Goals (SDGs) of the United Nations. It thus counts around 269 million people living in poverty (Planning Commission, 2013), approximately 500 million deprived of clean cooking fuel, 304 million having no access to electricity (NEP, 2017), 163 million without access to safe drinking water (WaterAid, 2018), close to 1.7 million people homeless (Census, 2011) and $48 \%$ of rural households lacking basic socio-economic services (SECC, 2015). Moreover, post-2020 climate commitments outlined in India's Nationally Determined Contribution (NDC) under the Paris agreement of the United Nations Framework Convention on Climate Change (UNFCCC) envision development along low-carbon emission pathways. India's enormous developmental needs have therefore to be balanced with emission reduction targets. The fact that coal produces nearly three fourth of electricity generated in India points at potentially high costs of emission control. In such conditions, achieving rapid economic growth and GHG mitigation targets concurrently can have substantial macroeconomic implications. Though climate action can help redress the trade unbalance via reduction of large fossil fuel imports, the transition to non-fossil fuels could be costly.

India has been growing at a remarkable GDP growth rate of 7-8\% annually since economic liberalization in 1991. The share of agriculture in GDP has gone down from $42 \%$ in 1970 to $17 \%$ in 2015 , and continues to decline. In 2016, services and industry sectors constituted $53 \%$ and $31 \%$ of GDP respectively (Economic Survey, 2018). The Indian manufacturing sector is expected to contribute more to GDP with implementation of government policies like Make in India, Smart Cities Mission and Housing for all. While the services sector has grown in the past much more than the manufacturing sector, programmes like Digital India, Start-up India and several other social 
programmes are likely to support the growth rate of service sector in future as well. Initiatives like increasing domestic production and substituting crude oil with cleaner fuels like bio-fuels have been taken recently with the idea of reducing dependence on crude oil imports, which are responsible for large trade deficit and raise energy security issues.

India has committed to reducing the GHG emission intensity of its GDP by $33 \%$ to $35 \%$ from 2005 levels as well as to raising the non-fossil contribution to its power generation capacity to $40 \%$, by 2030 (MoEFCC, 2015). To meet these targets, the Government of India (Gol) has taken several measures under the National Action Plan on Climate Change (NAPCC). It has set the target of building $175 \mathrm{GW}$ of renewable power capacity, including $100 \mathrm{GW}$ of solar power, by 2022. It has put emphasis on improving energy efficiency via several demand-side management initiatives and strict norms for the energy-intensive industries. Further, the Gol has taken a joint initiative with State Governments to provide $24 \times 7$ Power for All (PFA) by 2022. Though coal dominance as primary source of power generation in India is expected to continue in the near term, the government has rolled out clean coal policies to improve the efficiency of coal power plants (NEP, 2017). On the front of transport, it is promoting electric and hybrid vehicles through financial incentives, and imposing higher vehicle efficiency standards.

The motivation of this paper is therefore to capture the macroeconomic and energy implications of achieving development along low-carbon pathways. Several studies already investigate Indian mitigation pathways with focus on the transition of energy systems and its costs (Fragkos \& Kouvaritakis, 2018; Dubash et al., 2015; Lucas et al., 2013; Chaturvedi \& Shukla, 2014; Shukla et al., 2010; Shukla et al., 2015; van Ruijven et al., 2012). Some papers assess the implications of mitigation pathways for specific sectors like transport (Dhar et al., 2018; Dhar et al., 2017) or renewable energy supply (Shukla \& Chaturvedi, 2012; Mittal et al., 2016). As regards methodology, some papers adopt one of the two bottom-up and top-down approaches, while others attempt at integrated analysis. On the pure bottom-up front, Kumsar and Madlener (2016) apply the LEAP 
model to explore the challenge of reducing Indian power sector's coal intensity via deployment of renewable alternatives, in the face of rapidly increasing demand. Vishwanathan et al. (2018) explore the opportunities and challenges involved in meeting the mitigation goals associated with $2^{\circ} \mathrm{C}$ and well-below $2^{\circ} \mathrm{C}$ caps to global temperature increase using the AIM/Enduse model. However, by their bottom-up nature, both AIM/Enduse and LEAP models ignore any feedback of energy costs on energy demand or the wider economy, either through consumption or investment markets.

On the top-down front, analysis mostly builds on applications of multiregional Computable General Equilibrium (CGE) modelling tools as the prominent DART, EPPA, PACE or AIM/CGE models - van Ruijven et al. (2012) extensively survey pre-2012 studies. Recent studies like Mittal et al. (2018) use the India version of the AIM/CGE model to determine the GDP costs of mitigation. The Indian Planning Commission (2014) assesses the costs of adopting the low-carbon, inclusive growth strategy using a model that has some bottom-up technology information embedded within a topdown framework. Parikh (2012) provides a strategy to achieve sustainable development along lowcarbon pathways in India using a top-down econometric model and Integrated Energy Systems model. These models partially address the call for a better control of the interface between economic and technical systems (Hourcade et al., 2006) by improving their descriptions of energy supply, including via explicit mixes of discrete technologies. However, the rest of their structures remains anchored in the CGE paradigm, ill adapted to modelling either the inert, complex dynamics of energy demands or the specific constraints that development requirements exert on energy transition dynamics (Edenhofer et al., 2014). They also stick to the uniform pricing rule, which forbids proper treatment of heterogeneous pricing of homogeneous goods-typically, electricity or natural gas (Le Treut et al., 2017). The calibration source common to many of them, the GTAP database, departs from first-hand national sources through the statistical treatment required to balance international trade. The second-best features, of developing economies especially, such as administered prices, wages and exchange rate control elude the grasp of their implementations of the CGE paradigm. 
One particular instance of the Institute of Economic Growth (IEG) CGE model of Pradhan and Ghosh (2012) stands out by specifically focusing on the Indian economy. Notably, it builds on an original Social Accounting Matrix (SAM), and pays attention to the macroeconomic dimension of mitigation pathways by testing alternative closure rules. It also combines with the DART model in a commendable effort to articulate the national and international scales of analysis (Weitzel et al., 2015). However, it falls short from accommodating explicit physical energy statistics, either in its SAM or in modelling specifications. Johansson et al. (2015) suffers from similar calibration drawbacks for assessing the economic and energy implications of limiting the global temperature increase at $2^{\circ} \mathrm{C}$ above pre-industrial level by employing top-down IEG-CGE and bottom-up MARKAL-India models along with global models. Last but not least, Shukla et al. (2008) deploy a soft-coupling strategy combining the strengths of bottom-up (AIM/CGE) and top-down (MARKAL) approaches to explore low-carbon futures for India. However, the linkage only consists in the one-way feeding of AIM demand drivers into MARKAL, without any feedback in the form of, e.g., updated energy costs and attached investment requirements, thus only partially addressing consistency issues.

Our methodology of analysis of Indian low-carbon pathways focuses on filling up these methodological gaps. We couple the Asia-Pacific Integrated Model (AIM)/Enduse bottom-up optimization model to the top-down economy-wide IMACLIM model calibrated on original data reconciling national accounting and energy balance statistics. This method provides distinct advantages of analysing the energy-economy impact of interaction between mitigation policies and assumptions about structural change in the economy. Iteration to convergence warrants full consistency between the macroeconomics of IMACLIM and the energy-systems description of 
AIM/Enduse. The model makes use of up-to-date information from experts on energy systems and economy. ${ }^{1}$

With this hybrid tool, our primary objective is to contribute to national climate policy making by determining the macroeconomic implications of implementing the mitigation policies along with other socio-economic objectives. Our research focus is on improving the diagnostics about the policy questions on mitigation pathways in the Indian context. The need to design such policy packages that meet mitigation and development goals simultaneously is also highlighted in the fifth assessment report of the IPCC (Edenhofer et al., 2014). We inquire into the uncertainties involved at the interface of technological constraints in low-carbon pathways, and macroeconomic structural changes. This allows us to map the synergies and trade-offs associated with achieving the mitigation targets and economic goals simultaneously.

The rest of our article divides into 4 sections. We detail our modelling methodology in section 2 . We describe four mitigation and development scenarios in Section 3. We comment on scenario results in Section 4. In Section 5, we conclude and derive policy implications.

\section{Methodology}

The limitations of conventional top-down and bottom-up approaches of energy-economy modelling have been the focus of attention for years. While the top-down approach lacks technological explicitness, bottom up models fail to integrate macroeconomic feedbacks and microeconomic behaviours in their analysis (Grubb et al., 1993). Reconciling both approaches in energy/economy modelling is critical to producing comprehensive assessments of the expected impacts of mitigation

\footnotetext{
${ }^{1}$ We consulted energy-economy modelling experts from the International Centre for Research on Environment and Development (CIRED) (Paris, France), Intergovernmental Panel on Climate Change (IPCC) (Geneva, Switzerland), National Institute for Environmental Studies (NIES) (Tsukuba, Japan) and Indian Institute of Management Ahmedabad (IIMA) (Ahmedabad, India).
} 
on economic growth and other development goals. Additionally, the multiregional modelling tools that have produced international expertise on mitigation pathways lack flexibility to represent the increasingly country-specific nature of national mitigation courses. Our methodology addresses both these shortcomings by developing an original hybrid energy-economy modelling capacity for India, calibrated on harmonised data describing the Indian economy and energy systems (see Annex A and Gupta et al., 2018).

\subsection{The AIM/Enduse model of Indian energy systems}

On the side of energy systems, this methodology mobilises the AIM/Enduse model. AIM/Enduse is an energy-technology optimization model that minimizes the total costs of producing exogenous levels of energy services under constraint of a given portfolio of technologies (Kainuma et al., 2011). The Indian version of AIM/Enduse describes more than 450 supply and demand technologies (Pandey et al. 2003; Shukla, 2004). This model simulates the flow of fuels, materials and energy through a detailed sectoral representation of technologies. Our updated version incorporates additional details on technologies such as smart grids, electric vehicles, Carbon Capture, Utilization and Storage (CCUS) and battery storage (Vishwanathan et al., 2017; Vishwanathan et al., 2018). The exogenous parameters controlling AIM's modelling of energy systems are technology availability, technology mixes, device improvement coefficients, device lifetime, power capacity constraint, energy prices, technology costs, operational cost and technology efficiency while the technology transition is endogenous based on cost optimization.

\subsection{The IMACLIM-IND economy-wide model}

On the side of macroeconomics, our modelling architecture rests on the IMACLIM top-down model adapted to India (see Annex B for the comprehensive model formulary). Contrary to the standard CGE approach, IMACLIM does not postulate uniform behavioural specifications in all sectors. One important discrimination is between energy and non-energy sectors: while the latter 
are mostly modelled as standard 'nested' trade-off structures, the former are modelled under constraint of energy-systems expertise external to the model, in order to control the interface between economic and technical systems - one paramount dimension of any mitigation cost assessment (Hourcade et al., 2006).

This coupling to external expertise on energy systems is the most salient feature of IMACLIM (see section 2.3 below). It rests on calibration of the model on original hybrid data reconciling national accounting and energy flows and prices data (Annex A). Beyond that and the corresponding accounting consistencies, all macroeconomic specifications of the model are subject to revision depending on country specifics and the nature of pursued analyses. Concerning the growth engine, we base IMACLIM-IND on Harrod- neutral technical progress via exogenous labour productivity gains. Our attention to 2030 and 2050 horizons prompts us to implement IMACLIM-IND in comparative statics between our 2012 calibration year and either one of these end years. This induces simplifying capital dynamics by implementing a simple link of proportionality between the total capital stock and investment flows, rather than the accumulation rule of dynamic models. The rental price of capital standardly clears the capital market by adjusting those sectoral capital demands that are not informed by AIM/Enduse (see below) to the consecutive level of capital supply, considering substitution possibilities to labour in the value-added of non-energy sectors. To acknowledge the specific degree of competition on each Indian goods or services market, IMACLIMIND calibrates the capital demand of sectors on their consumptions of fixed capital only and models net operating surpluses as fixed mark-ups (mark-up pricing). IMACLIM-IND also considers labour market imperfections i.e. involuntary unemployment by ways of an aggregate wage curve (Blanchflower and Oswald, 2005).

The macroeconomics of IMACLIM-IND are specific in two additional, important dimensions. First, real investment, whose increase drives that of the capital stock, flows from exogenous assumptions on India's investment effort. To reflect trends observed in other developing and 
developed economies, we postulate a decrease from the uncommonly high level of $37.0 \%$ of GDP in 2012 to $30.6 \%$ in 2030 and $26.0 \%$ in 2050 . Balance on the investment market happens via adjustment of domestic savings, under constraint of foreign savings dictated by the endogenous trade balance (see below): we settle on Johansen closure for IMACLIM-IND (Sen, 1963). Similar to Johansen, our justification is that of assuming public policies incentivizing a sustainable investment effort, rather than letting possible misalignments of the domestic savings rate and trade balance compromise growth.

Second, rather than exogenously fixing the trade balance and letting the unemployment rate adjust following the wage curve (via freely adjusting terms-of-trade inducing purchasing power shifts), we chose to keep the unemployment rate fixed and let the trade balance adjust, under the maintained constraint of the wage curve. This is to avoid postulating the impact of transition pathways on the trade balance considering the large share of fossil energy in imports and the large current trade deficit. By targeting one unemployment rate, we are in fact forcing a specific level of relative domestic versus import prices via the wage curve. This in turn induces a specific trade balance via import and export price-elasticities. The policy interpretation is that of the Gol controlling the Indian exchange rate to maintain unemployment at the current low level, which turns out to mean allowing real wages to reflect labour productivity gains. ${ }^{2}$ The resulting trade deficits at both the outlook horizons and for all our scenarios means that India will keep on relying on foreign capital flows to sustain its economic growth.

\footnotetext{
${ }^{2}$ Standard CGE applications rather assume total wage flexibility to reach full employment, under one specific exogenous trade balance objective-commonly, an exact equilibrium, which is the condition to self-sufficiency on the savings and investment market. The drawback of such model closure is the absence of control of the compared evolutions of the real wage and labour productivity, as well as the instantaneous resorption of any trade improvement into an increase of general activity-i.e. the inability to report trade improvements.
} 
Our choice of Johansen closure implies stability of real GDP across scenario variants via stability of investment dynamics and hence the capital stock-although relative price shifts may translate identical efforts as GDP shares in slightly different real investment dynamics. Scenario differentiation will rather appear in contrasted evolutions of final consumption (via domestic savings) and the cumulated trade deficit (via foreign savings). We adjust our reports of scenario results accordingly.

Besides the evolution of the activity shares of energy supplies as flowing from AIM/Enduse data (see below), IMACLIM-IND models structural change via shifts of the sectoral composition of final demand (share of gross fixed capital formation, budget allocation of household consumption) and the impact of endogenous terms-of-trade on exports and the domestic contribution to total supply. The budget allocation of households follows AIM/Enduse for energy goods, responds to income according to constant elasticities for 7 out of 14 non-energy goods, ${ }^{3}$ and follows a CobbDouglas assumption of fixed shares-concentrated on services for close to $95 \%$ - for the budget remainder.

\subsection{Coupling AIM/Enduse and IMACLIM-IND}

We couple AIM/Enduse and IMACLIM via the iterative exchange of modelling outputs of one model as inputs to the other model, up to convergence of the set of shared variables. This method warrants that any economic outlook of IMACLIM is backed by one fully consistent, detailed energy systems outlook of AIM/Enduse. The resulting 'hybrid' architecture thus combines the strengths of bottom-up and top-down energy/economy modelling (Ghersi et al., 2006, Hourcade et al., 2006, Kriegler et al., 2015). Ghersi (2015) presents the theoretical understanding of the coupling and

\footnotetext{
${ }^{3}$ Income elasticities drive households' demand for agriculture, textile, residual industries, air transport, road transport, rail transport and housing.
} 
elaborates on the distinct advantages of performing it through iterative exchange of variables to convergence, rather than with the use of reduced forms of bottom-up responses.

The convergence process starts with running IMACLIM under specific scenario assumptions to produce sectoral end-use demands. We force these demands into AIM to produce energy-related outputs, which we feed back into IMACLIM. We check whether the carbon emissions of the updated IMACLIM run respect our postulated national cap in the context of a $2^{\circ} \mathrm{C}$ global effort (see section 3 below). If not, we apply carbon caps in AIM to force such targets. We run AIM and feedback energyrelated outputs into IMACLIM. We iterate this process until energy-economy-emissions outputs are stabilised (Figure 1).

To analyse the macroeconomic implications, we set up IMACLIM-IND to detail 22 sectors, 8 of which energy sectors-coal, coke, crude oil and non-transport fuels, transport fuels, biomass, natural gas, electricity, renewables (which mainly supply the electricity sector); and 14 non-energy sectors-iron \& steel, chemicals \& petrochemicals, aluminium, cement, construction, textile, residual industries, agriculture, air transport, water transport, road transport, rail transport, housing services and a remainder of other services (see Annex A for description). The AlM outputs that we force into IMACLIM range from the main energy intensities of 22 productive sectors to households' energy consumptions, the capital intensities of 8 energy supplies and 5 non-energy but energyintensive supplies namely iron \& steel, chemicals \& petrochemicals, aluminium, cement and textile. We chose to rely more on the engineering insights delivered by AIM/Enduse than on the nested-CES production functions of the standard CGE, although we maintain that sort of substitutability outside AIM coverage. 


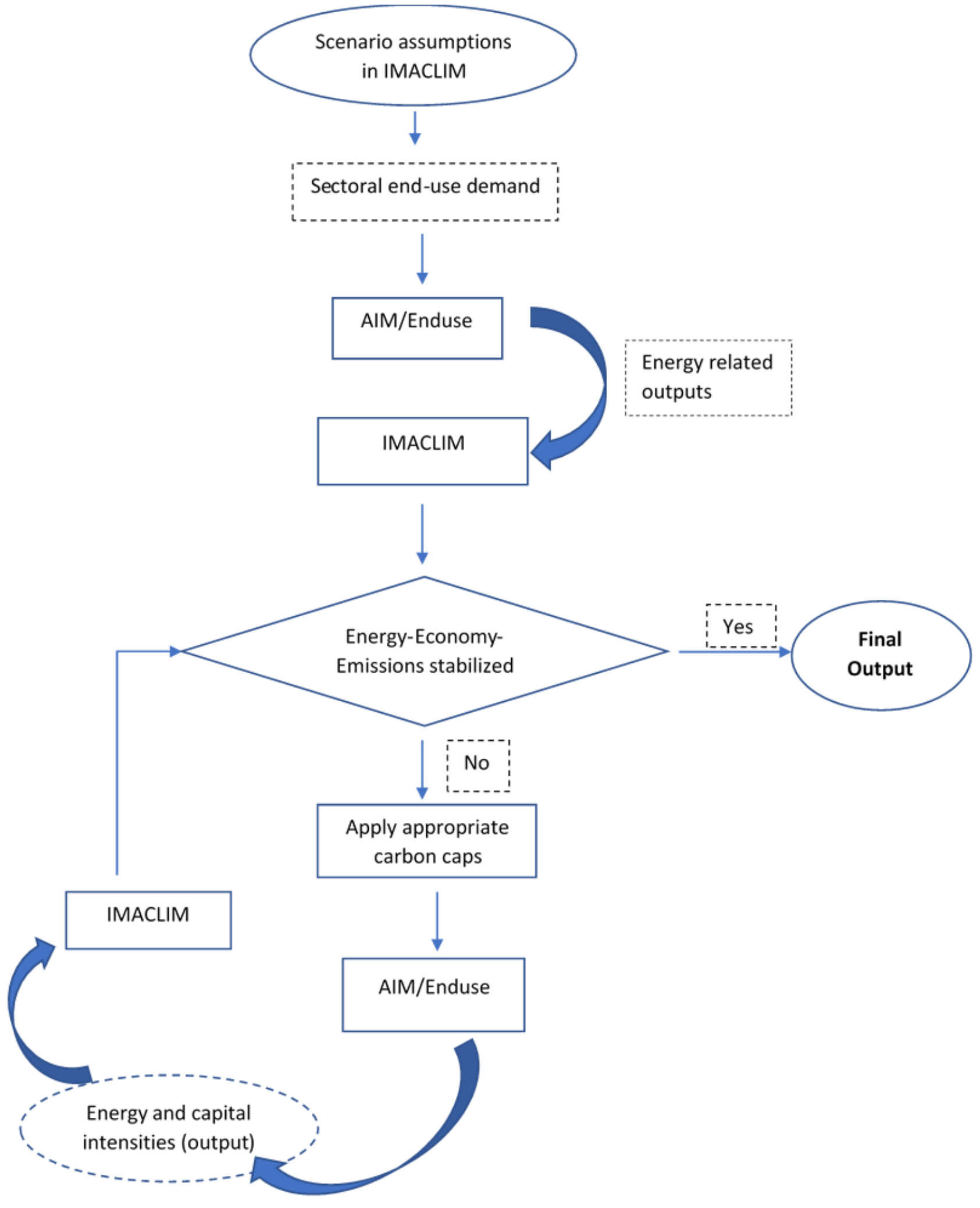

Figure 1 Illustration of iteration process 


\section{Scenario architecture}

We model and project at 2030 and 2050 milestones four scenarios comprising one business as usual (BAU) scenario and three scenarios of further carbon constraint, in line with potential Indian contribution to global action targeting a $2^{\circ} \mathrm{C}$ cap on global temperature increase, differentiated by lower, middle (BAU) and higher growth dynamics. The purpose of this differentiation is to determine the feasibility and related trade-offs of achieving high growth in a low-carbon economy.

\subsection{Business As Usual (BAU) scenario}

Our BAU scenario follows the current pattern of emissions and development dynamics, taking account of the recent energy and climate change policies and commitments as outlined in NAPCC (PMCoCC, 2008) and Indian NDC submitted to UNFCCC (MoEFCC, 2015).

The BAU strategy for mitigation includes National Missions in areas like solar energy, enhanced energy efficiency, sustainable habitat, green India and sustainable agriculture (PMCoCC, 2008), and the State Action Plans on Climate Change (SAPCC) consistent with NAPCC prepared by 32 States/Union Territories. In particular, this scenario includes the voluntary goal announced by India to reduce the emission intensity of its GDP by 33-35\% from 2005 levels by 2030 (MoEFCC, 2015). Other supplementing strategies include policies like the National Electricity Policy (NEP) (2005), that focusses on universalizing access to electricity, the National Policy for Farmers (NPF) (2007) and National Mission on Sustainable Agriculture (NMSA), which underscores the sustainable development of agriculture, and the Energy Conservation Act (2001), which encourages the efficient use of energy.

Regarding factors shaping economic growth, we assume India's population to grow at $1.06 \%$ annually on average from 2013 to 2030 , thus reaching 1,527 million people by 2030 and 1,705 million people by 2050 (UNPD, 2015). Structural changes in labour market yield an increase of 1.57\% per year of labour endowment finally reaching 644 million and 744 million workers in 2030 and 2050 
respectively, based on past trends and population projections from the United Nations (2015) and ILO (2018). India is growing at a fast pace currently. However, in the long term, growth is expected to slow down as it did in developing countries. A logistic curve is often used to represent this kind of trend. Our long-term projections for potential growth over the years 2018-2050 are determined by estimating such a curve using past trends, expert opinion and experience from developed countries (Shukla et al., 2004). We assume that the productivity of Indian labour grows at a fast pace with average annual growth rate of $4.9 \%$ from 2012 to 2030 and $4.8 \%$ from 2030 to 2050 (Table 1). As previously stated (see section 2.2), we consider constant unemployment at 2.23\% (National Sample Survey Office (NSSO) (2013) and Mehrotra et al. (2014)) of total labour supply, and a decreasing rate of investment or Gross Fixed Capital Formation (GFCF) as investment needs shift from infrastructure development to retrofitting and replacement.

The structure of the BAU energy system and induced CO2-emission trajectory reflect current dynamics curbed by announced policy constraints. We put capacity constraints in the power sector to increase the role of renewables like solar, wind and hydro. We further constrain increased use of energy-efficient technologies and cleaner fuels in energy-intensive sectors.

Table 1 Main assumptions for four scenarios 


\begin{tabular}{|c|c|c|c|c|}
\hline & $\begin{array}{l}\text { Business As Usual } \\
\text { (BAU) }\end{array}$ & $\begin{array}{l}2 \text { Degree Medium } \\
\text { Growth (2DegMG) }\end{array}$ & $\begin{array}{l}2 \text { Degree High } \\
\text { Growth (2DegHG) }\end{array}$ & $\begin{array}{l}2 \text { Degree Low } \\
\text { Growth (2DegLG) }\end{array}$ \\
\hline Labour supply & $\begin{array}{l}+1.57 \% \text { per year from } \\
2013 \text { to } 2030 \text { then } \\
+0.72 \% \text { from } 2030 \text { to } \\
2050\end{array}$ & $\begin{array}{l}+1.57 \% \text { per year from } \\
2013 \text { to } 2030 \text { then } \\
+0.72 \% \text { from } 2030 \text { to } \\
2050\end{array}$ & $\begin{array}{l}+1.57 \% \text { per year from } \\
2012 \text { to } 2030 \text { then } \\
+0.72 \% \text { from } 2030 \text { to } \\
2050\end{array}$ & $\begin{array}{l}+1.57 \% \text { per year from } \\
2012 \text { to } 2030 \text { then } \\
+0.72 \% \text { from } 2030 \text { to } \\
2050\end{array}$ \\
\hline Labour productivity & $\begin{array}{l}+4.9 \% \text { per year from } \\
2013 \text { to } 2030 \text { then } \\
+4.8 \% \text { from } 2030 \text { to } \\
2050\end{array}$ & $\begin{array}{l}+4.9 \% \text { per year from } \\
2013 \text { to } 2030 \text { then } \\
+4.8 \% \text { from } 2030 \text { to } \\
2050\end{array}$ & $\begin{array}{l}+5.8 \% \text { per year from } \\
2013 \text { to } 2030 \text { then } \\
+5.8 \% \text { from } 2030 \text { to } \\
2050\end{array}$ & $\begin{array}{l}+3.9 \% \text { per year from } \\
2013 \text { to } 2030 \text { then } \\
+3.8 \% \text { from } 2030 \text { to } \\
2050\end{array}$ \\
\hline $\begin{array}{l}\text { Resulting potential } \\
\text { growth rate }\end{array}$ & $\begin{array}{l}+6.5 \% \text { per year from } \\
2013 \text { to } 2030 \text {, then } \\
+5.6 \% \text { from } 2030 \text { to } \\
2050\end{array}$ & $\begin{array}{l}+6.5 \% \text { per year from } \\
2013 \text { to } 2030 \text {, then } \\
+5.6 \% \text { from } 2030 \text { to } \\
2050\end{array}$ & $\begin{array}{l}+7.5 \% \text { per year from } \\
2013 \text { to } 2030 \text {, then } \\
+6.6 \% \text { from } 2030 \text { to } \\
2050\end{array}$ & $\begin{array}{l}+5.5 \% \text { per year from } \\
2013 \text { to } 2030 \text {, then } \\
+4.6 \% \text { from } 2030 \text { to } \\
2050\end{array}$ \\
\hline Energy policy & NAPCC, NDC & $\begin{array}{l}\text { Advanced NDC, CCS } \\
\text { in power plants and } \\
\text { energy-intensive } \\
\text { industries }\end{array}$ & $\begin{array}{l}\text { More renewables, } \\
\text { higher energy } \\
\text { efficiency, more CCS, } \\
\text { BECCS }\end{array}$ & $\begin{array}{l}\text { NAPCC, NDC (less } \\
\text { advanced) }\end{array}$ \\
\hline $\begin{array}{l}\text { Behavioural change } \\
\text { over BAU }\end{array}$ & None & $\begin{array}{l}\text { More public } \\
\text { transport, } \\
\text { dematerialization, } \\
\text { waste recycling }\end{array}$ & $\begin{array}{l}\text { Sustainable actions in } \\
\text { all sectors, public \& } \\
\text { shared transport, } \\
\text { dematerialization, } \\
\text { demand reduction, } \\
\text { waste recycling }\end{array}$ & None \\
\hline $\begin{array}{l}\text { Cumulative } \mathrm{CO}_{2} \\
\text { emissions (Billion } \\
\text { tons) from energy, } \\
2011 \text { to } 2050 \text {. }\end{array}$ & 165 & 123 & 123 & 123 \\
\hline
\end{tabular}

\subsection{2-Degree scenarios}

We consider three 2-Degree scenario variants labelled as 2-Degree Medium Growth (2DegMG), 2-Degree High Growth (2DegHG) and 2-Degree Low Growth (2DegLG). We cap the cumulative carbon emissions from 2011-2050 at 123 billion tons of $\mathrm{CO}_{2}$ in all three scenarios. However, assumptions concerning labour productivity, energy policies, technology deployment and behavioural changes vary (Table 1 ).

The 2-Degree Medium Growth (2DegMG) scenario builds on the productivity growth of the BAU but considers mitigation targets for the period 2021 to 2030 higher than those submitted under the Paris Agreement. It aims at reducing the emission intensity of GDP by 40 to 45 percent below 2005 level by 2030. To attain such objectives, we set advanced targets for the share of renewables and deployment of new technologies in the coal, power, buildings, industries and transport sectors. 
We refer to various government websites, official documents, and statements and presentations by government officials for our assumptions on advanced targets (see Annex C for details and references).

- In the power sector, we phase out low-efficiency coal-based power plants and facilitate the switch to energy-efficient technologies like super-critical pulverized coal and Integrated Gasification Combined Cycle (IGCC) power plants via exogenous constraints on the technology mix. This induces higher capital mobilization in the power sector.

- We assume that energy-intensive industries become more energy-efficient through implementation of the Perform, Achieve and Trade (PAT) scheme ${ }^{4}$ with extended coverage of sectors such as Micro, Small and Medium Enterprises (MSMEs).

- Public transport systems like Dedicated Freight Corridors (DFCs) and railways play a prominent role for reducing the carbon emissions from transport. We set the technology-share constraints in AIM/Enduse to favour low-carbon mobility modes like electric vehicles and rail. We adjust the energy-intensity of freight transport to reflect generalisation of DFCs.

- In order to meet the stricter carbon cap, we consider Carbon Capture and Storage (CCS) technologies in power generation and energy-intensive industry sectors.

- Additionally, we consider a set of behavioural changes that contribute to abate households emissions. More people opt to work from home, thereby reducing passenger transport demand. Households adopt more efficient cooking, heating and lighting technologies to limit the increase

\footnotetext{
${ }^{4}$ PAT scheme is part of National Mission on Enhanced Energy Efficiency (NMEEE) implemented by Bureau of Energy Efficiency (BEE) under Ministry of Power. PAT is a market-based mechanism where energy-saving certificates can be traded by specified energy-intensive industries.
} 
of residential consumptions. Besides, methods to reduce, reuse and recycle materials are encouraged, thereby reducing the intensity of GDP in newly produced materials.

The 2-Degree High Growth (2DegHG) scenario assumes higher average annual labour productivity growth of 5.8\% from 2013 to 2050 (Table 1) following recent trends (CEIC, 2018). The underlying assumption is that productivity gains do not slow down in the long term but keep on advancing at the same pace. Since higher economic growth is envisaged, more resources could be invested in meeting SDGs over and above those already deployed for them in the medium growth scenario. However, higher growth would also lead to increased energy demand by industries like iron and steel, cement, chemicals and petrochemicals, textile, aluminium and residual industries along with demand for transport, construction and other services. Maintaining India on low-carbon pathways limiting global temperature rise to $2^{\circ} \mathrm{C}$ above pre-industrial levels therefore requires further energy-systems transformations.

- The energy consumption of the services sector is critical considering that it is the fastest growing sector in India and currently constitutes the largest share of Indian GDP. Our 2DegHG scenario consequently extends the adoption of energy-efficient appliances and of solar energy to services.

- We assume further modal shift towards electric vehicles and shared transport to target reduction of end-use demand of petrol and diesel.

- On the front of household consumptions, the 2DegHG variant assumes quicker generalisation of clean cooking options (electric, LPG and natural gas) thus eliminating the dependence on inefficient cooking fuels like firewood by 2050 .

- In order address the risk of increased emissions, we consider the adoption of disruptive technologies such as electric furnaces in the iron \& steel sector and alternate materials to 
replace cement or steel in construction of buildings, roads, ports and other infrastructure.

Besides, we significantly reduce heat losses and assume generalised waste-heat recovery.

The 2 Degree Low Growth (2DegLG) scenario assumes average labour productivity growth of $3.9 \%$ per year from 2013 to 2030 and $3.8 \%$ per year from 2030 to 2050 . The carbon-emission constraint remains identical, but lower growth makes it easier to meet, allowing less stringent innovation in carbon-intensive sectors. This should allow mobilizing slightly cheaper, more carbonintensive technologies in AIM/Enduse. Lower capital costs feeding back to IMACLIM-IND could allow higher growth i.e. a smaller efficiency gap between potential growth (labour supply $\mathrm{x}$ labour productivity increases) and actual growth.

\section{Results and discussion}

We first explore the energy dynamics for our reference scenario (BAU), which emulates the current policy, socio-economic and energy prospects. We find that coal dominance persists from base year 2012 (BY2012) up to 2050, although the contributions of renewables, ${ }^{5}$ biomass and natural gas increase as a result of current climate policies (Figure 2). This is expected as the demand for all goods in Indian economy, which is largely fossil-dependent, is growing rapidly. In 2050, power generation is the largest buyer of energy and coal dominates its mix (Figure 2). Other large energyconsuming sectors are residual industries, transport, iron \& steel and other services. Coal, transport fuels (TRANSPFUEL), non-transport fuels (OILNTFUEL) and natural gas constitute major shares of energy consumption in BAU2050. As India is largely dependent on imports for meeting demand of fossil fuels such as crude oil, natural gas and coal, it must have macroeconomic repercussions.

\footnotetext{
${ }^{5}$ To facilitate the forcing of AIM/Enduse investment trajectories, we single out renewables into one production sector, whose output's exclusive use is as input to the electricity sector.
} 


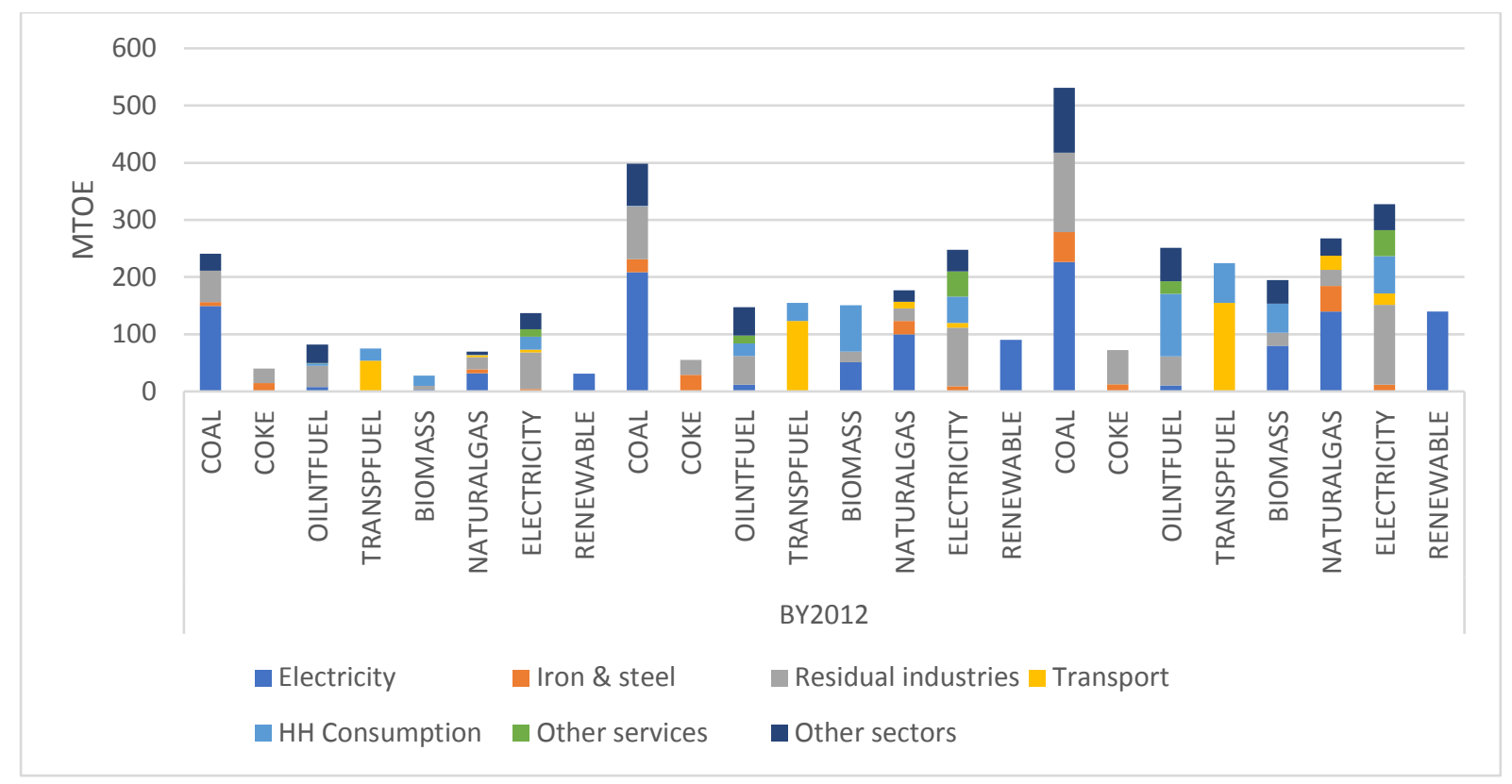

Figure 2 Sector-wise share of energy supply in BAU scenario.

Source: IMACLIM-IND and AIM/Enduse coupled simulations. The reported supply is the specific supply of commercial flows as tracked by the output volumes of CGE models. BY2012 stands for "base year 2012". HH consumption stands for "household consumption".

Our focus in the paper being macroeconomic assessment, we now turn to investigating the macroeconomic results of all scenarios for both horizon years (Table 2). As regards real GDP, scenarios expectedly perform according to their potential growth assumptions, i.e. the lower growth scenario less than the BAU and middle growth scenarios, and the latter scenarios less than the higher growth scenario. At 2030, the 2-degree scenarios perform 0.1 percentage point below their potentials (compare Table 1 to Table 2), while the BAU is 0.2 points below potential. Comparison between 2DegMG and BAU, who share the same labour productivity assumptions, reveals that the low-carbon constraint is compatible with maintained and indeed slightly increased economic activity, despite its higher investment costs in energy supply and demand (see below), which translate into a higher ratio of energy expenses to GDP. This is at least under our assumptions of 
public policies controlling the investment effort (Johansen closure) and adjusting the exchange rate to warrant real wages increasing as labour productivity (our trade specification). As we indicated in Section 2.2, these specifications require qualifying activity results with attention to domestic and foreign savings evolutions.

Table 2 Macroeconomic results of all scenarios

\begin{tabular}{|c|c|c|c|c|c|c|c|c|c|}
\hline & \multirow{2}{*}{$\begin{array}{r}2012 \\
\text { BY2012 }\end{array}$} & \multicolumn{4}{|c|}{2030} & \multicolumn{4}{|c|}{2050} \\
\hline & & BAU & 2DegMG & 2DegHG & 2DegLG & BAU & 2DegMG & 2DegHG & 2DegLG \\
\hline $\begin{array}{l}\text { Real GDP (Trillion } \\
\text { US dollar 2012) }\end{array}$ & 1.7 & 5.2 & 5.3 & 6.3 & 4.5 & 14.4 & 14.6 & 19.9 & 10.5 \\
\hline $\begin{array}{l}\text { Average annual } \\
\text { real GDP growth } \\
\text { (\%) (2013 } \\
\text { onwards) }\end{array}$ & - & $6.3 \%$ & $6.4 \%$ & $7.4 \%$ & $5.4 \%$ & $5.7 \%$ & $5.8 \%$ & $6.6 \%$ & $4.8 \%$ \\
\hline $\begin{array}{l}\text { Trade balance } \\
\text { ratio to GDP (\%) }\end{array}$ & $-7.4 \%$ & $-9.6 \%$ & $-8.8 \%$ & $-8.0 \%$ & $-10.0 \%$ & $-10.6 \%$ & $-9.4 \%$ & $-7.8 \%$ & $-12.7 \%$ \\
\hline $\begin{array}{l}\text { Household } \\
\text { consumption ratio } \\
\text { to GDP (\%) }\end{array}$ & $60 \%$ & $68.1 \%$ & $67.3 \%$ & $66.5 \%$ & $68.5 \%$ & $69.0 \%$ & $67.9 \%$ & $66.3 \%$ & $71.1 \%$ \\
\hline $\begin{array}{l}\text { Foreign debt ratio } \\
\text { to GDP (\%) }\end{array}$ & $-128 \%$ & $-149 \%$ & $-133 \%$ & $-113 \%$ & $-160 \%$ & $-218 \%$ & $-183 \%$ & $-132 \%$ & $-286 \%$ \\
\hline $\begin{array}{l}\text { E imports ratio to } \\
\text { GDP }\end{array}$ & $10.0 \%$ & $9.2 \%$ & $8.2 \%$ & $7.1 \%$ & $10.0 \%$ & $8.4 \%$ & $7.3 \%$ & $4.4 \%$ & $11.4 \%$ \\
\hline $\begin{array}{l}\text { E expenses ratio } \\
\text { to GDP }\end{array}$ & $22.3 \%$ & $24.5 \%$ & $25.2 \%$ & $23.4 \%$ & $26.1 \%$ & $28.2 \%$ & $26.9 \%$ & $26.5 \%$ & $31.0 \%$ \\
\hline $\begin{array}{l}\text { Emission intensity } \\
\text { (ktCO2eq per } \\
1000 \text { US\$ 2012) }\end{array}$ & 1.1 & 0.8 & 0.6 & 0.5 & 0.7 & 0.4 & 0.2 & 0.1 & 0.2 \\
\hline
\end{tabular}

The impact of scenarios on foreign savings follows on their trade impacts. The 2-degree scenarios reduce the weight of energy imports only in their medium and high growth variants, whereas low growth increases it. Under our assumption of endogenous trade, reduced energy imports translate into improved trade balances compared to BAU, although terms-of-trade appreciation mitigates the improvement. Because of our choice of trade specification, the improved trade balance does not affect activity but reduces the cumulated foreign debt. However, it also 
constitutes an effective decrease of foreign savings. This decrease prompts a compensating increase of domestic savings, which in turn decreases household consumption.

Comparison of the BAU and 2DegMG scenarios summarises the revealed macroeconomic trade-offs. By 2050 and under the assumption of appropriate investment and exchange rate policies, the low-carbon pathway has the potential to reduce the foreign debt significantly (a 35-GDP point decrease) via improvement of the trade balance, at the consumption cost of ca $1 \%$ of GDP, while slightly improving activity. In the event of high growth, the low-carbon option achieves close to maintaining foreign debt at its base-year level (+4 GDP points only by 2050) by further decreasing the share of household consumption in GDP by 1.6 points-but for a largely improved GDP. Conversely, the BAU trajectory and even more so the low-growth low-carbon trajectory lead to dramatic increases of the foreign debt (respectively +90 and +158 GDP points by 2050) via increased trade deficits.

Turning to activity composition, the 2030 GDP shares of industries, agriculture and services decrease in the 2DegMG scenario compared to BAU (Figure 3). The reason is that the share of valueadded mobilized by energy sectors is higher in the 2DegMG scenario because of the higher capital costs of the technologies required to achieve advanced mitigation targets: super-critical and ultrasuper-critical coal based power plants, Carbon Capture and Storage (CCS) options, Integrated Gasification Combined Cycle (IGCC) and Pressurized Fluidised Bed Combustion (PFBC). By 2050, however, the GDP share of industries also increases, under the combined pressure of the increased capital intensity induced by penetration of energy-efficient techniques (as depicted by AIM) and the increased rental price of capital induced by the consecutive pressure on capital demand-which affects capital-intensive industrial activities more than other activities. The higher investment costs of meeting the same mitigation objectives in the higher growth scenario show both in the increased share of energy sectors (+1.9 GDP points in 2050) and industries (+2 GDP points in 2050). 


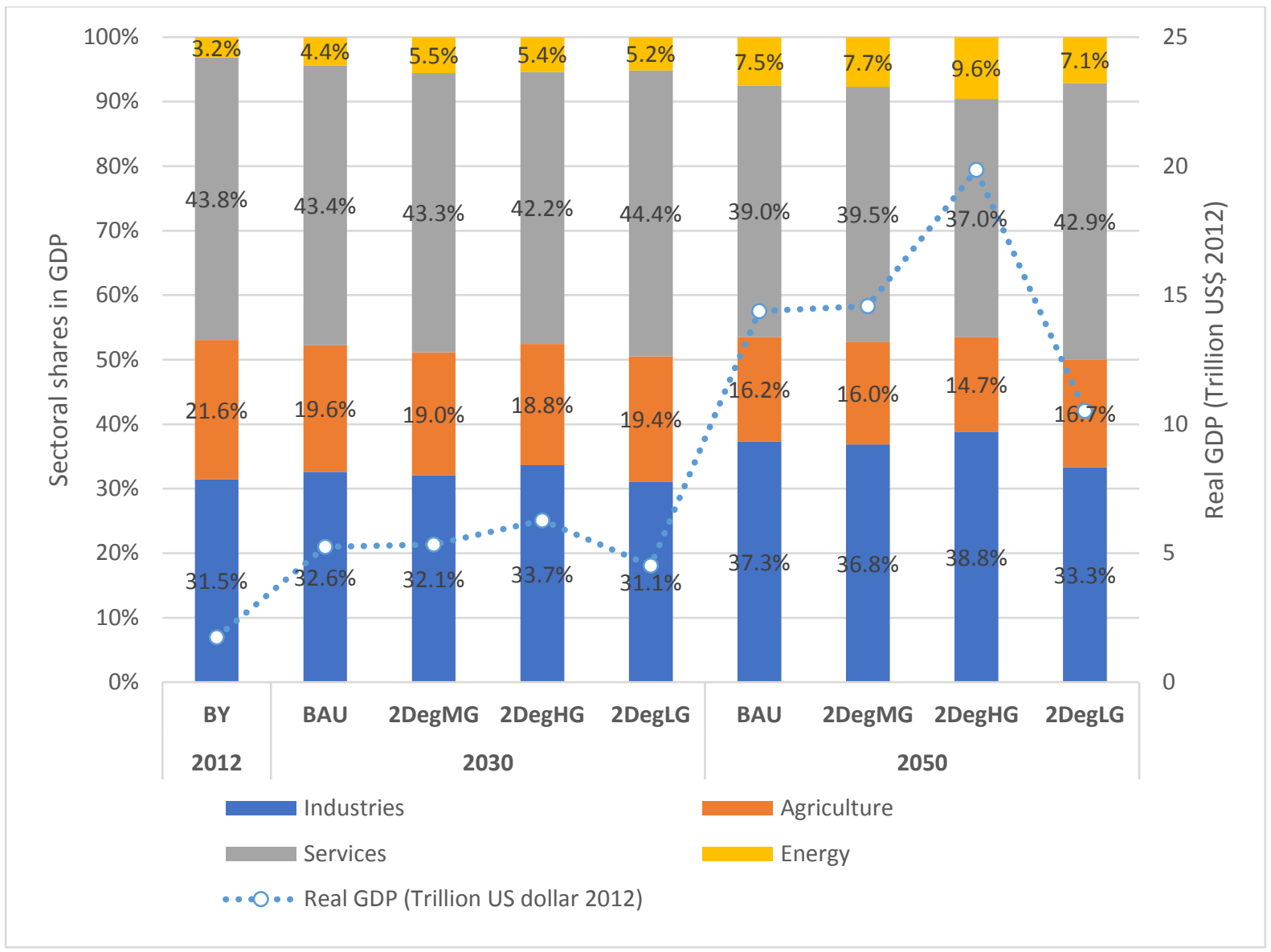

Figure 3 Total GDP and sectoral breakdown at base year (BY) 2012, in 2030 and 2050

Past data on infrastructure investment in India show that more than $40 \%$ of the total investments have been going into the energy supply sector (OECD, 2014). Nearly 77 billion USD have been invested in energy supply annually on average since 2010 (IEA, 2015). However, this capital infusion might not be sufficient to achieve low-carbon scenarios in the future. By 2030, the gap with respect to BAU investment is 12.6 Billion USD in the 2DegMG scenario, while it increases to 26.1 billion USD in the 2DegHG scenario (Table 3). Assuming constant growth rates from 2012 on, this amounts to a cumulative increase of 300 billion USD in energy supply investment from 2015 to 2040 in the 2DegMG scenario compared to BAU. This is a significant amount compared to the estimated cumulative investment in Indian energy supply of around 2 trillion USD from 2015 to 2040 in the New Policies Scenario of the International Energy Agency, which mainly considers the NDCs 
submitted to UNFCCC (IEA, 2015). In the 2DegHG scenario, capping carbon emissions at the same level as in the 2DegMG scenario induces rising capital costs to support 'green' high growth.

\section{Table 3 Gap to BAU of 2030 investments in energy supply for low-carbon scenarios}

\begin{tabular}{lcc}
\hline & $\begin{array}{c}\text { Energy supply investment } \\
\text { (Billion 2012 USD) }\end{array}$ & $\begin{array}{c}\text { Gap to BAU } \\
\text { (Billion 2012 USD) }\end{array}$ \\
\hline 2DegMG & 223.7 & 12.6 \\
2DegHG & 237.2 & 26.1 \\
2DegLG & 159.9 & -51.1 \\
\hline
\end{tabular}

*Projections of energy supply investments for 2030 from IMACLIM-IND model

Further sectoral detail reveals that the increase of energy supply investment under tighter carbon constraint (comparing 2DegMG to BAU) happens both in the power sector and in non-fossil energy supply, i.e. renewables and biomass supply (Figure 4). Beyond energy sectors, the transport and housing sectors also register significant investment increases prompted by the development of public transports and the relatively high income-elasticity of housing services consumption. The substantially higher growth of the 2DegHG scenario induces increased investment expenses in all sectors. Particularly, non-fossil energy supply mobilises largely higher resources to allow meeting the carbon constraint under increased activity. Conversely, the 2DegLG scenario has investment expenses lower than the BAU except, interestingly, for the power sector, whose capital efficiency appears decreased. 


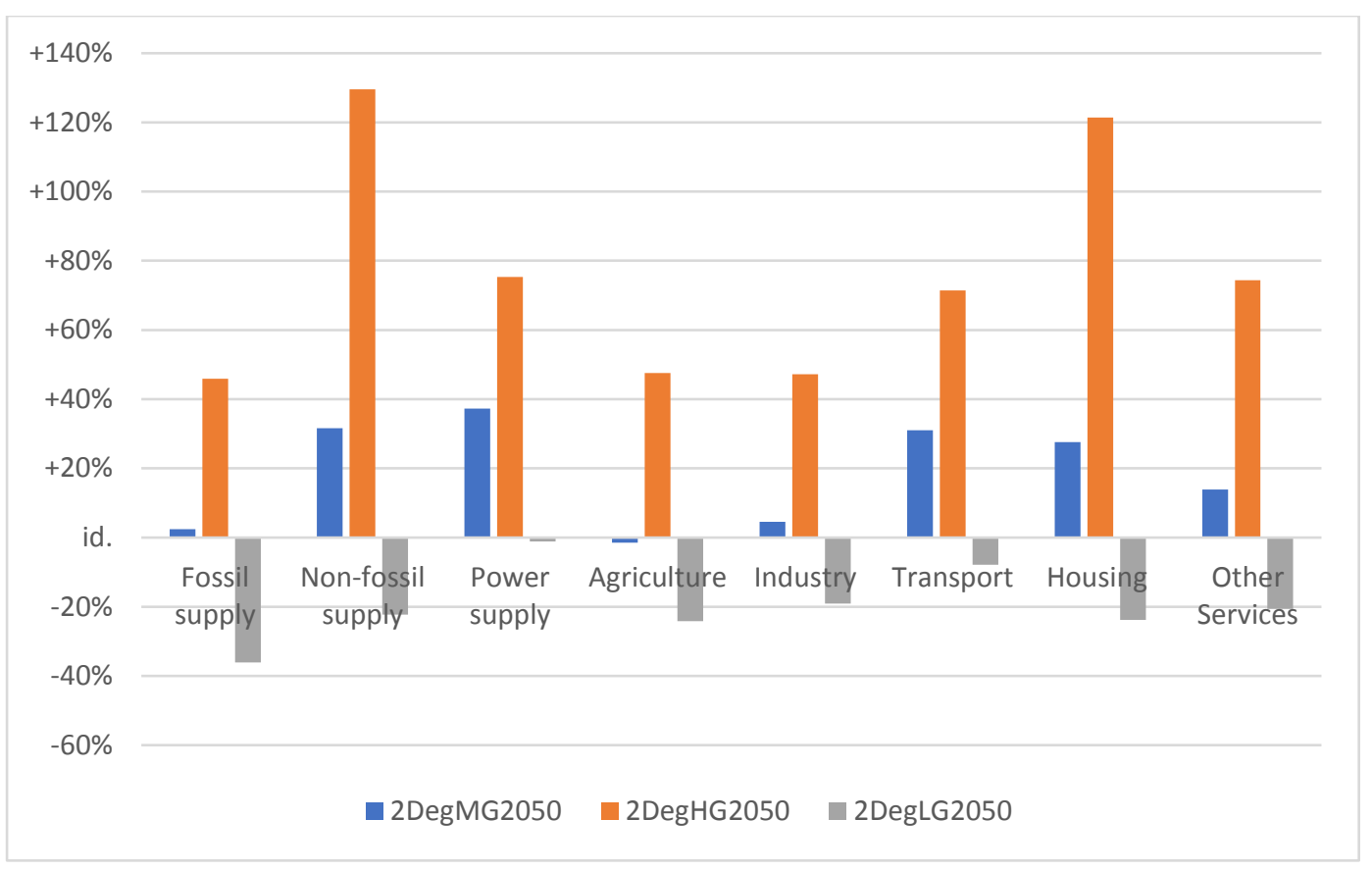

Figure 4 Variations of 2050 sectoral investments for three scenarios compared to BAU

Compared to $\mathrm{BAU}$, the higher carbon constraint enforced on $2^{\circ} \mathrm{C}$ scenarios results in decreased (commercial) energy intensity and increased capital intensity of aggregate energy supply (Table 4). These are endogenous results of AIM/Enduse under our climate policy assumptions, forced into IMACLIM-IND with consistency on all considered feedbacks after iteration to convergence. In the high-growth scenario, the capital intensity of aggregate energy supply diverges by $+0.6 \%$ on average annually from 2012 to 2050 , while its energy intensity diverges by $-0.3 \%$, compared to BAU. This affects real GDP to some extent, as testifies the larger gap between realised growth (at $6.6 \%$ annual average) and potential growth (at $7.0 \%$ annual average).

Table 4 Deviations of energy and capital intensity of energy supply from BAU to $2^{\circ} \mathrm{C}$ scenarios

\begin{tabular}{lccc}
\hline & 2DegMG & 2DegHG & 2DegLG \\
\hline $\begin{array}{l}\text { Energy intensity variation from BAU } \\
\text { (on average annually from 2012 to 2050) * }\end{array}$ & $-0.11 \%$ & $-0.34 \%$ & $-0.04 \%$ \\
$\begin{array}{l}\text { Capital intensity variation from BAU } \\
\text { (on average annually from 2012 to 2050) * }\end{array}$ & $+0.12 \%$ & $+0.57 \%$ & $+0.03 \%$ \\
\hline *On average for all energy supply sectors of IMACLIM-IND, not accounting for solar and wind inputs to power.
\end{tabular}


In the 2DegHG scenario, coal remains the mainstay of the Indian power sector up until 2030.

It is also the main energy source for energy-intensive industries. Consequently, significant investment goes into clean coal technologies. By 2050, older inefficient coal plants have phased out, renewables have developed and battery and pumped storage technologies provide cost-effective energy-storage options to guarantee grid reliability. The aggregate capital intensities of energy supply increases and the aggregate energy-intensity of energy supply decreases correspondingly (Table 4). In the 2DegLG scenario, the energy efficiencies of the technologies used in various industrial sectors are low and the capital input per unit output is less, comparatively. The contribution of renewables to power generation does increase in the long term but the energy efficiency of the electricity sector remains low.

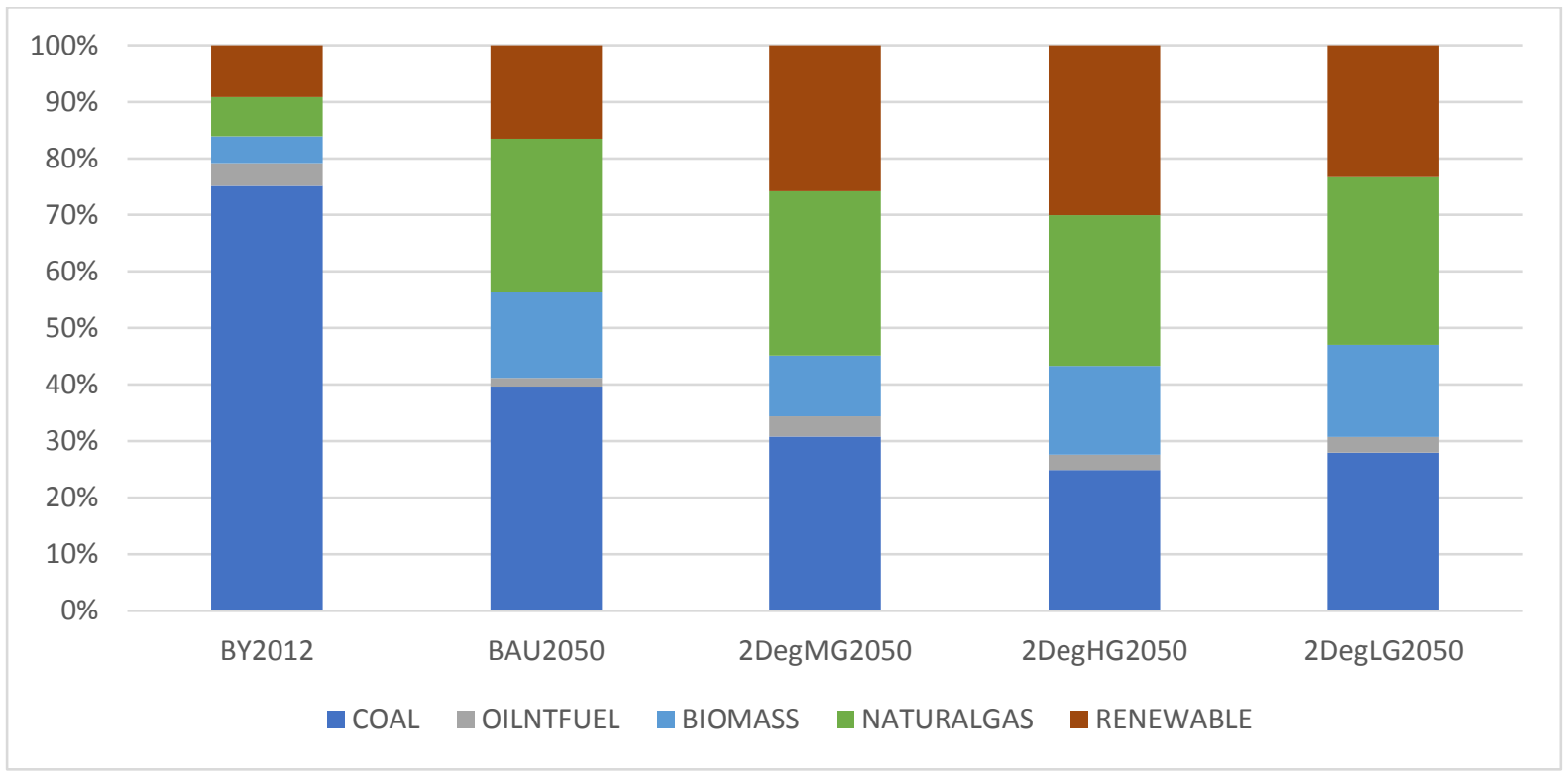

Figure 5 Power generation by source in 2012 and for 4 scenarios in 2050

All scenarios enforce carbon constraints that induce shifts of the energy mixes and consumption choices of all agents. One key source of emissions is the power sector. The 165Bt carbon constraint in BAU allows maintained coal dominance. The more stringent $123 \mathrm{Bt}$ constraint of $2^{\circ} \mathrm{C}$ scenarios translates into renewables and natural gas gaining shares (Figure 5). Another 
important source of emissions is households' energy consumptions. The constraints translate in a drastic decline of transport fuels consumptions in the medium growth scenario, mainly due to the shift to electric vehicles and public transport (Figure 6a). Non-transport fuels (OILNTFUEL) consumptions decline as well due to the massive substitution of electric stoves and solar cookers to kerosene and firewood stoves. Under the 2DegHG scenario, all households' energy consumptions increase compare to 2DegMG because of substantially higher income. However, the consumptions of fossil fuels remain below BAU levels (compare Figures $6 a$ and $6 b$ ).

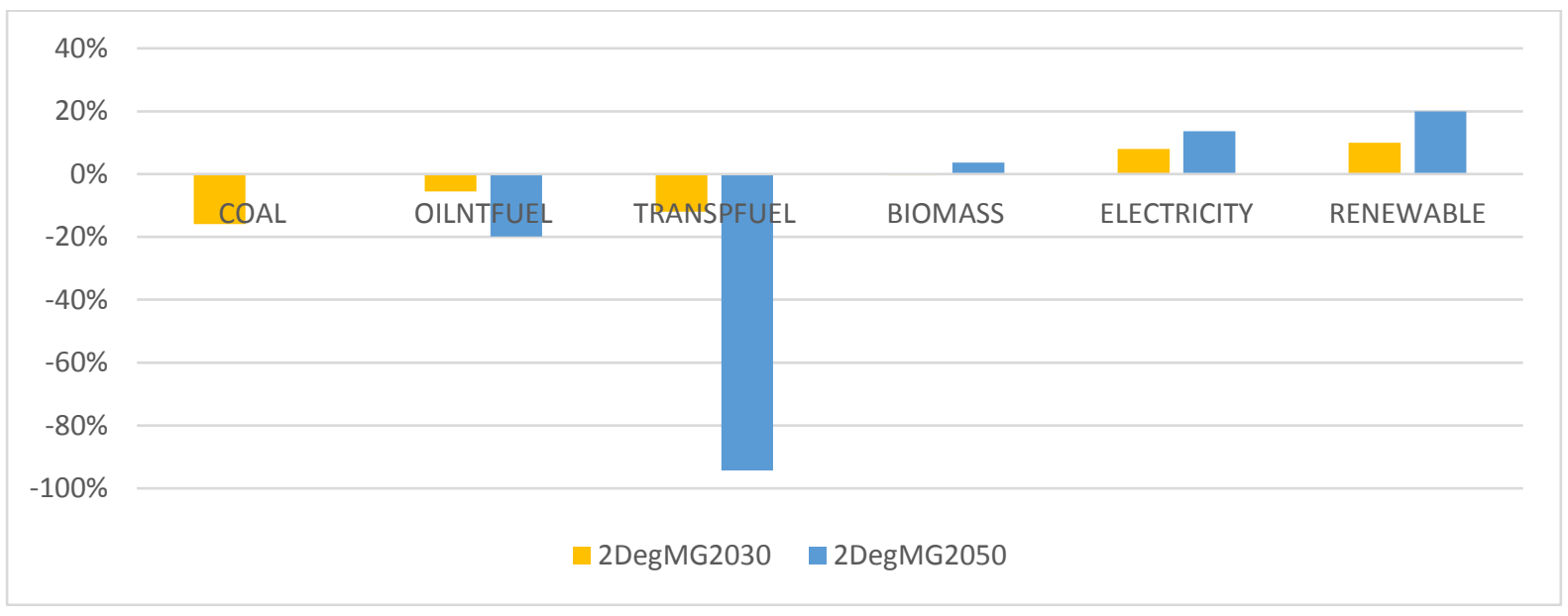

Figure 6a Household consumption change (\%) in 2DegMG scenario compared to BAU

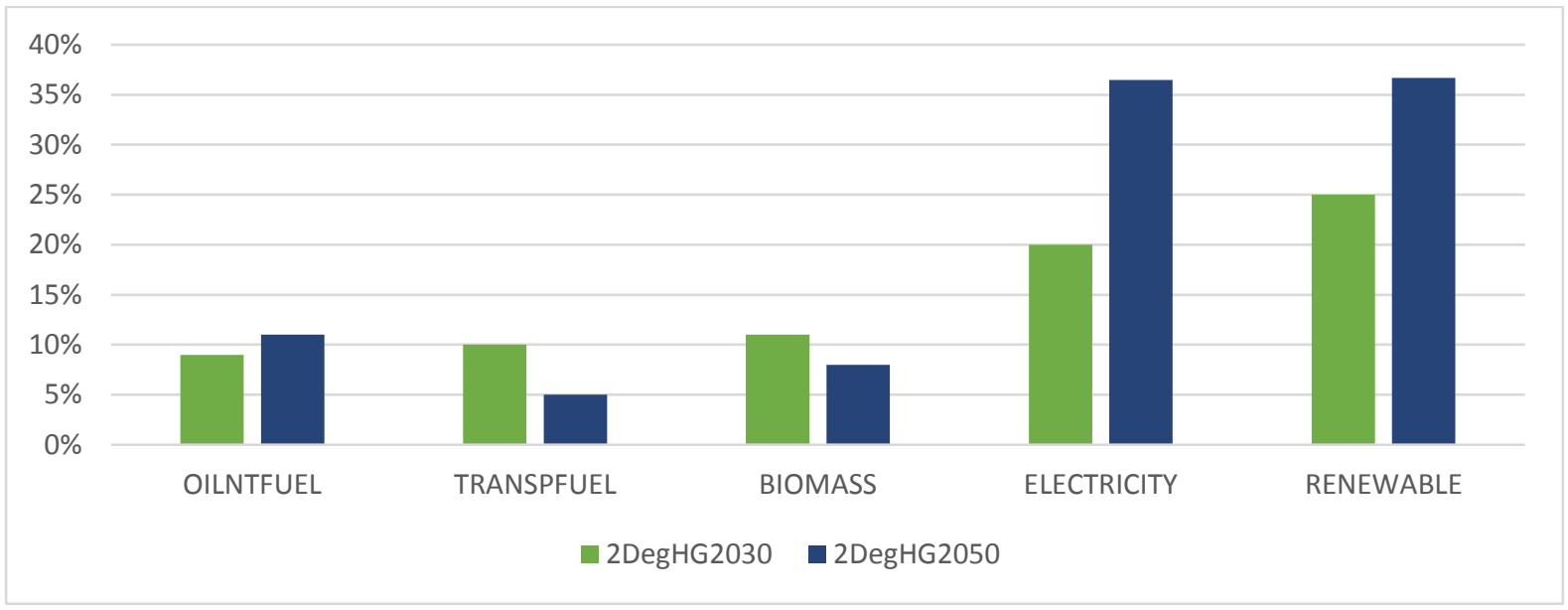

Figure $6 \mathrm{~b}$ Household consumption change (\%) in 2DegHG scenario compared to 2DegMG 
Overall, the 2DegHG scenario stands out as not only the one with higher activity-somewhat by construction, but also because the costs of capping emissions do not weigh enough on national income to overly increase the gap to potential growth-but also the one with the lower trade balance deficit, which allows it to keep the Indian foreign debt under control. The main trade-off for these results is the lower share of GDP devoted to household consumption because of lower foreign savings. Another trade-off, hardly perceptible at our level of aggregation, is the potential employment loss and financial and strategic loss of certain stakeholders in carbon-intensive activities or technologies during the process of low-carbon transition. Measures that could allow a smooth transition include retraining and job creation for workers in carbon intensive sectors, similar to what Germany provided to its ex-coal miners; "just transitions" where all stakeholders are affected equitably; "golden handshakes" consisting in single lump-sum payment to harmed employees such as Poland gave to workers in retreating sectors including again coal mining (Caldecott et al., 2017).

Our results additionally show that the capital intensity of energy supply increases significantly in the 2DegHG scenario to support clean growth and higher energy efficiency. This puts pressure on the rental price of capital considering limited supply. More pressure on investment markets comes from making energy-efficient the fast growing sectors of iron \& steel and cementto the point that the GDP share of industries increases in the long term in our $2^{\circ} \mathrm{C}$ scenarios compared to BAU. High growth can thus be clean but this requires more investment in non-fossil power generation and technology upgrades in energy-intensive industries like iron \& steel, cement, aluminium and textile. In the event of higher growth, the services sector becomes critical because of its increasing contribution to GDP and hence to energy consumption. Behavioural changes in both the services sector and households' actions will be necessary to achieve the low carbon targets with high growth.

We acknowledge the fact that our modelling framework has a fixed technology portfolio and that there is a chance that actual technical progress by 2050 eludes its grasp. There is for instance 
the possibility of transformation of fundamental end-uses such as graphene replacing cement; there is also the possibility of some technological breakthrough allowing transition to a fully non-fossil economy. The probabilities of such extreme transformations is low enough for our projected futures to provide valuable insights about achieving economic development along low-carbon pathways.

\section{Conclusion and policy implications}

This article applies the coupling of the IMACLIM-IND economy-wide and the AIM/Enduse energy systems models to determine the implications of low-carbon pathways on India's economic development. We draw the following conclusion and policy implications from our analysis. First, lowcarbon policy measures like stringent energy-efficiency requirements, promotion of electric vehicles and shared transport, switch to non-fossil power generation and incentives for behavioural adjustments are compatible with high growth targets. Further, low-carbon pathways reduce the dependence on imported fossil fuels like crude oil and natural gas and increase the consumption of renewables like solar and wind. This has significant implications for the energy security of a country like India, which currently depends on imported fuels to meet its ever-increasing energy demands. In addition, on low-carbon pathways the energy required per unit of economic output reduces as a consequence of energy-efficiency measures. Overall, our macroeconomic analysis underlines that this leads to improvements of the trade balance. However, our scenarios build on optimisation of energy systems and specific macroeconomic policies. These imply that policymakers need to decide investments judiciously to achieve the twin goals of high growth and low-carbon economy concurrently. Additionally, the switch to green technologies and non-fossil energy sectors in a fossilbased economy like India can possibly lead to various socio-economic issues such as job losses in certain sectors, or financial and strategic risks for specific companies. Therefore, policymakers need to reconcile the conflicting interests of entrenched businesses in retreating sectors like coal and oil and the emerging low-carbon technologies like renewables. 
Second, a fast developing country like India with increasing population and rapid urbanization has huge investment needs. Large shares of this investment should go into energy supply to support green growth through the objective of $2^{\circ} \mathrm{C}$-compatible emissions. However, our projections show that most of the required energy supply investment will only be redirected to lowcarbon options, while incremental investment only amounts to less than $6 \%$ of current trends (NDC) investment. Part of this investment shall come from international finance, but the current Indian trade deficit proves unsustainable if prolonged to 2050 and it is one of the desirable side effects of the low-carbon transition to reduce this deficit and keep foreign debt under control and to increase the share of domestic savings in investment supply.

Third, our results suggest that energy-efficiency improvements are pivotal but with the caveat that they require increases of the capital intensity of energy-intensive productive sectors. The thrust lies on driving the low-carbon pathways early on before the technological or behavioural lockins build-up. It is critical that lock-in of capital in fossil fuel based technologies is avoided to achieve transition towards a low-carbon high-growth economy. This will entail continuous evaluation of climate policies.

Fourth, we should bear in mind that the technology portfolio that backs our scenario developments requires investment in research and development to bring about technology disruptions. Technology transfer to developing countries like India will be vital to avoid the delay in action. Lastly, as India experiences structural change in the future, large number of Small and Medium Enterprises (SMEs) are expected to rise, prompting shifts of a large share of the working population from agriculture to industries and services. It is important that these enterprises employ capital to build up sustainable practices and techniques. In conclusion, the objective of policymakers should be to stir the development of all economic sectors towards low-carbon high-growth objectives. High economic growth will require higher finances and technologies to transit to low- 
carbon pathways, which could be internally provided by labour productivity gains and economies of scale, as well as by external investments.

\section{Declaration of interest statement}

None.

\section{Funding}

This research was partially funded by DDP BIICS project with IKI number 18_I_326_Global_A_Climate Action After Paris. Development of the IMACLIM model benefits from support of the Chair LongTerm Modelling for Sustainable Development (Ponts Paristech-Mines Paristech) funded by Ademe, GRT-Gaz, Schneider Electric, EDF, RTE, Total and the French ministry of Environment.

\section{References}

Gupta, D., Ghersi, F., \& Garg, A. (2018). "Hybrid Input-Output tables for India at year 2012", Mendeley Data, v2. https://doi.org/10.17632/d7ffryvtjk.2

Blanchflower, D., \& Oswald, A. (2005). The Wage Curve Reloaded. Cambridge, MA. https://doi.org/10.3386/w11338

Caldecott, B., Sartor, O., \& Spencer, T. (2017). Lessons from previous "Coal Transitions": High Level Summary for Decision Makers. Paris and London: IDDRI and Climate Strategies. Retrieved from www.coaltransitions.org

CEIC. (2018). India Labour Productivity Growth [1992 - 2018]. Retrieved June 25, 2018, from https://www.ceicdata.com/en/indicator/india/labour-productivity-growth

Census. (2011). Census of India Website : Office of the Registrar General \& Census Commissioner, 
India. Retrieved June 15, 2018, from http://censusindia.gov.in/2011-

Common/CensusData2011.html

Central Electricity Authority. (2018). National Electricity plan- Ministry of Power, Government of India. Retrieved from http://www.cea.nic.in/reports/committee/nep/nep_jan_2018.pdf

Chaturvedi, V., \& Shukla, P. R. (2014). Role of energy efficiency in climate change mitigation policy for India: assessment of co-benefits and opportunities within an integrated assessment modeling framework. Climatic Change, 123(3-4), 597-609. https://doi.org/10.1007/s10584013-0898-x

Coal Controller's Organisation. (2015). Coal Directory of India 2013-2014 Coal Statistics. Government of India. Ministry of Coal. Controller's Organization. Kolkata. Retrieved from https://www.coal.nic.in/sites/upload_files/coal/files/curentnotices/coaldir13-14_0.pdf

CSO. (2016). Supply and Use Table, A note on Compilation for the years 2011-12 and 2012-13. Central Statistics Office, Ministry of Statistics and Programme Implementation. Retrieved from http://mospi.nic.in/sites/default/files/reports_and_publication/statistical_publication/National _Accounts/SUT_Methodology_final_noteforwebsite.pdf

Department of Atomic Energy. (2015). DAE sets target of reaching an installed generation capacity of 63000 MW by the year 2031-32 -Department of Atomic Energy, Government of India. Retrieved June 16, 2018, from http://pib.nic.in/newsite/PrintRelease.aspx?relid=120008

Dhar, S., Pathak, M., \& Shukla, P. R. (2017). Electric vehicles and India's low carbon passenger transport: a long-term co-benefits assessment. Journal of Cleaner Production, 146, 139-148. https://doi.org/10.1016/J.JCLEPRO.2016.05.111

Dhar, S., Pathak, M., \& Shukla, P. R. (2018). Transformation of India's transport sector under global warming of $2{ }^{\circ} \mathrm{C}$ and $1.5^{\circ} \mathrm{C}$ scenario. Journal of Cleaner Production, 172, 417-427. https://doi.org/10.1016/J.JCLEPRO.2017.10.076 
Dubash, N. K., Khosla, R., Rao, N. D., \& Sharma, K. R. (2015). Informing India's energy and climate debate: policy lessons from modelling studies. Retrieved from http://pure.iiasa.ac.at/id/eprint/11644/1/Informing India\%27s Energy and Climate Debate_CPR-IIASA.pdf

Economic Survey. (2018). Economic Survey 2017-18. Retrieved from http://mofapp.nic.in:8080/economicsurvey/

Edenhofer, O., Pichs-Madruga, R., Sokona, Y., Farahani, E., Kadner, S., Seyboth, K., ... Kriemann. (2014). Climate Change 2014: Mitigation of Climate Change. Contribution of Working Group III to the Fifth Assessment Report of the Intergovernmental Panel on Climate Change. Cambridge, United Kingdom and New York, USA: Cambridge University Press.

Fragkos, P., \& Kouvaritakis, N. (2018). Model-based analysis of Intended Nationally Determined Contributions and $2{ }^{\circ} \mathrm{C}$ pathways for major economies. Energy, 160, 965-978. https://doi.org/10.1016/J.ENERGY.2018.07.030

Ghersi, F. (2015). Hybrid Bottom-up/Top-down Energy and Economy Outlooks: A Review of IMACLIM-S Experiments. Frontiers in Environmental Science, 3(November), 1-18. https://doi.org/10.3389/fenvs.2015.00074

Ghersi, F., \& Hourcade, J. C. (2006). Macroeconomic Consistency Issues in E3 Modeling : The Continued Fable of the Elephant and the Rabbit. The Energy Journal, 27(2006), 39-61.

Gol. (2015). Ministry of Skill Development and Entrepreneurship: Key Achievements and Success Stories in 2015. Retrieved June 22, 2018, from http://pib.nic.in/newsite/PrintRelease.aspx?relid=133233

Government of India. (2017). Booklet on Pathways for Accelerated Transformation in Industry SectorGovernment of India. Retrieved from https://beeindia.gov.in/sites/default/files/Final Booklet 29-9-2017.pdf 
Government of India. The Gazette of India. Ministry of Petroleum and Natural Gas Notification (2018). Retrieved from http://petroleum.nic.in/sites/default/files/biofuelpolicy2018_1.pdf

Grubb, M., Edmonds, J., Ten Brink, P., \& Morrison, M. (1993). The costs of limiting fossil-fuel CO2 emissions: a survey and analysis. Annual Review of Energy and the Environment, 18, 397-478. Retrieved from www.annualreviews.org

Henderson, C. (2015). Coal-fired power plant efficiency improvement in India. London, United Kingdom: IEA Clean Coal Centre. Retrieved from www.iea-coal.org Hourcade, J., Jaccard, M., Bataille, C., \& Ghersi, F. (2006). Hybrid modeling: New Answers to Old Challenges Introduction to the Special Issue of "The Energy Journal." The Energy Journal, 1-11. Retrieved from https://www.jstor.org/stable/23297043

IEA. (2015). World Energy Outlook 2015. Paris, France: International Energy Agency.

ILO. (2018). Employment by sex and age - ILO modelled estimates. Retrieved from https://www.ilo.org/ilostat/

IRENA. (2017). Renewable Energy and Jobs - Annual Review 2017. International Renewable Energy Agency. Retrieved from https://www.irena.org/documentdownloads/publications/irena_re_jobs_annual_review_2017. pdf

Johansen, L. (1960). A multi-sectoral study of economic growth. Amsterdam. Retrieved from http://searchenginepdf.info/a-multi-sectoral-study-of-economic-growth-download-or-printtxt-leif-johansen.pdf

Johansson, D. J. A., Lucas, P. L., Weitzel, M., Ahlgren, E. O., Bazaz, A. B., Chen, W., ... Wei, Y.-M. (2015). Multi-model comparison of the economic and energy implications for China and India in an international climate regime. Mitigation and Adaptation Strategies for Global Change, 20(8), 1335-1359. https://doi.org/10.1007/s11027-014-9549-4 
Kainuma, M., Matsuoka, Y., \& Morita, T. (2011). Climate policy assessment: Asia-Pacific integrated modeling. Springer Science \& Business Media.

Kriegler, E., Petermann, N., Krey, V., Schwanitz, V. J., Luderer, G., Ashina, S., ... Van Vuuren, D. P. (2015). Diagnostic indicators for integrated assessment models of climate policy. Technological Forecasting and Social Change, 90, 45-61. https://doi.org/10.1016/J.TECHFORE.2013.09.020

Kumar, S., \& Madlener, R. (2016). CO2 emission reduction potential assessment using renewable energy in India. Energy, 97, 273-282. https://doi.org/10.1016/J.ENERGY.2015.12.131

Le Treut, G. (2017). Methodological proposals for hybrid modelling : consequences for climate policy analysis in an open economy (France) (Doctoral dissertation, École Doctorale Ville, Transports et Territoires (VTT)-ED 528). Retrieved from https://hal.archives-ouvertes.fr/tel-01707559/

Lucas, P. L., Shukla, P. R., Chen, W., van Ruijven, B. J., Dhar, S., den Elzen, M. G. J., \& van Vuuren, D. P. (2013). Implications of the international reduction pledges on long-term energy system changes and costs in China and India. Energy Policy, 63, 1032-1041. https://doi.org/10.1016/J.ENPOL.2013.09.026

Mehrotra, S., Parida, J., \& ... S. S. (2014). Explaining employment trends in the Indian economy: 199394 to 2011-12. Economic and Political Weekly, 49(32), 49-57.

Ministry of Heavy Industries \& Public Enterprises. (2017). Initiatives for production of electric Vehicles- Government of India. Retrieved June 16, 2018, from http://pib.nic.in/newsite/mbErel.aspx?relid=169437

Ministry of Housing and Urban Affairs. (2017). METRO RAIL POLICY-2017 (Government of India). Retrieved from http://mohua.gov.in/upload/whatsnew/59a3f7f130eecMetro_Rail_Policy_2017.pdf Ministry of Power. (2016). National Led Bulbs Scheme Gets a New Face in 'UJALA' - Ministry of Power, Government of India. Retrieved June 16, 2018, from 
http://pib.nic.in/newsite/PrintRelease.aspx?relid=137826

Ministry of Power. (2017). PM launches Pradhan Mantri Sahaj Bijli Har Ghar Yojana "Saubhagya"Ministry of Power, Government of India. Retrieved June 16, 2018, from http://pib.nic.in/newsite/PrintRelease.aspx?relid=171101

Ministry of Road Transport \& Highways. (2018). Port Development and Integrated Inter-Modal Transport in India. Retrieved from https://www.unescap.org/sites/default/files/India_CBStrengthening Transport_March_0.pdf

Mittal, S., Dai, H., Fujimori, S., \& Masui, T. (2016). Bridging greenhouse gas emissions and renewable energy deployment target: Comparative assessment of China and India. Applied Energy, 166, 301-313. https://doi.org/10.1016/J.APENERGY.2015.12.124

Mittal, S., Liu, J.-Y., Fujimori, S., \& Shukla, P. (2018). An Assessment of Near-to-Mid-Term Economic Impacts and Energy Transitions under " $2{ }^{\circ} \mathrm{C}$ " and " $1.5^{\circ} \mathrm{C}$ " Scenarios for India. Energies, 11(9), 2213. https://doi.org/10.3390/en11092213

MoEFCC. (2015). India's intended nationally determined contribution: Working towards climate justice. Retrieved from https://www4.unfccc.int/sites/ndcstaging/PublishedDocuments/India First/INDIA INDC TO UNFCCC.pdf

NITI Aayog. (2017). Draft National Energy Policy NITI Aayog, Government of India. Retrieved from https://niti.gov.in/writereaddata/files/new_initiatives/NEP-ID_27.06.2017.pdf

NSSO. (2013). Key Indicators of Employment and Unemployment in India 2011-12. NSS 68th Round. New Delhi: National Sample Survey Office, Ministry of Statistics and Programme Implementation, Government of India. Retrieved from http://mospi.nic.in/sites/default/files/publication_reports/KI-68th-E\%26U-PDF.pdf

OECD. (2014). OECD Economic Surveys: India 2014. Paris, France: OECD Publishing. https://doi.org/http://dx.doi.org/10.1787/eco_surveys-ind-2014-en 
Pachauri, S. (2007). An energy analysis of household consumption : changing patterns of direct and indirect use in India. Springer.

Pandey, R., \& Shukla, P. R. (2003). Methodology for Exploring Co-benefits of CO2 and SO2 Mitigation Policies in India using AIM/Enduse model. In Climate Policy Assessment (pp. 113-122). Tokyo: Springer Japan. https://doi.org/10.1007/978-4-431-53985-8_7

Parikh, K. (2012). Sustainable development and low carbon growth strategy for India. Energy, 40(1), 31-38. https://doi.org/10.1016/J.ENERGY.2012.01.013

Planning Commission. (2014). The Final Report of the Expert Group on Low Carbon Strategies for Inclusive Growth. Retrieved from http://planningcommission.nic.in/reports/genrep/rep_carbon2005.pdf

Planning Commission. (2013). Press Note on Poverty Estimates, 2011-12. Government of India, Planning Commission. Retrieved from http://planningcommission.nic.in/news/pre_pov2307.pdf

PMCoCC. (2008). National Action Plan on Climate Change. Retrieved from http://moef.gov.in/wpcontent/uploads/2018/04/NAP_E.pdf

Pradhan, B., \& Ghosh, J. (2012). The Impact of Carbon Taxes on Growth Emissions and Welfare in India: A CGE Analysis (No. IEG Working Paper No. 315). Retrieved from http://sa.indiaenvironmentportal.org.in/files/file/The Impact of Carbon Taxes on Growth Emissions and Welfare in India.pdf

Press Information Bureau. (2017a). India's Changing Transport Landscape- Government of India, Special Service and Features. Retrieved June 17, 2018, from http://pib.nic.in/newsite/printrelease.aspx?relid=169766

Press Information Bureau. (2017b). Union Cabinet approves new Metro Rail Policy; Focus on compact urban development, cost reduction and multi-modal integration. Retrieved June 17, 
2018, from http://pib.nic.in/newsite/erelease.aspx?relid=170009

Press Information Bureau. (2018a). Cabinet approves enhancement of target under Pradhan Mantri Ujjwala Yojana- Cabinet Committee on Economic Affairs (CCEA), Government of India. Retrieved June 17, 2018, from http://pib.nic.in/newsite/PrintRelease.aspx?relid=176351

Press Information Bureau. (2018b). Year Ender-3-AMRUT 2018- Ministry of Housing and Urban Poverty Alleviation, Government of India. Retrieved June 17, 2018, from http://pib.nic.in/newsite/PrintRelease.aspx?relid=186779

Reuters. (2011). Recession cuts U.S., Russia 2009 greenhouse emissions. Retrieved June 16, 2018, from https://in.reuters.com/article/idINIndia-56369520110415

SECC. (2011). Socio-Economic Caste Census-2011. Retrieved June 15, 2018, from https://secc.gov.in/welcome

Sen, A. K. (1963). Neo-Classical and Neo-Keynesian Theories of Distribution. Economic Record, 39(85), 53-64. https://doi.org/10.1111/j.1475-4932.1963.tb01459.x

Shukla, P. (2004). Climate policy assessment for India: applications of Asia-Pacific integrated model (AIM). Universities Press.

Shukla, P., Dhar, S., Pathak, M., Mahadevia, D., \& Garg, A. (2015). Pathways to deep decarbonization in India. SDSN - IDDRI. Retrieved from http://orbit.dtu.dk/en/publications/id(b30a20bf-1f284cde-ad40-db7653a2e018).html

Shukla, P. R., \& Chaturvedi, V. (2012). Low carbon and clean energy scenarios for India: Analysis of targets approach. Energy Economics, 34, S487-S495.

https://doi.org/10.1016/J.ENECO.2012.05.002

Shukla, P. R., Dhar, S., \& Fujino, J. (2010). Renewable energy and low carbon economy transition in India. Journal of Renewable and Sustainable Energy, 2(3), 031005. 
https://doi.org/10.1063/1.3411001

Shukla, P. R., Dhar, S., \& Mahapatra, D. (2008). Low-carbon society scenarios for India. Climate Policy, 8(sup1), S156-S176. https://doi.org/10.3763/cpol.2007.0498

The Economic Times. (2018). Renewable energy target now $227 \mathrm{GW}$, will need $\$ 50$ billion more in investments. Retrieved June 16, 2018, from https://economictimes.indiatimes.com/industry/energy/power/india-will-add-225-gwrenewable-energy-project-capacity-by-2022-r-k-singh/articleshow/64461995.cms

United Nations. (2015). World Population Prospects The 2015 Revision. New York: Department of Economic and Social Affairs. Population Division. Retrieved from https://esa.un.org/unpd/wpp/Publications/Files/WPP2015_Volume-I_ComprehensiveTables.pdf

UNPD. (2015). Probabilistic Population Projections based on the World Population Prospects: The 2015 Revision. Population Division, DESA. Retrieved from http://esa.un.org/unpd/ppp/

van Ruijven, B. J., van Vuuren, D. P., van Vliet, J., Mendoza Beltran, A., Deetman, S., \& den Elzen, M. G. J. (2012). Implications of greenhouse gas emission mitigation scenarios for the main Asian regions. Energy Economics, 34, S459-S469. https://doi.org/10.1016/J.ENECO.2012.03.013

Vishwanathan, S., Garg, A., Tiwari, V., \& Kankal, B. (2017). Enhancing energy efficiency in India: Assessment of sectoral potentials. Copenhagen: Copenhagen Centre on Energy Efficiency, UNEP DTU Partnership.

Vishwanathan, S. S., Garg, A., Tiwari, V., \& Shukla, P. R. (2018). India in $2{ }^{\circ} \mathrm{C}$ and well below $2{ }^{\circ} \mathrm{C}$ worlds: Opportunities and challenges. Carbon Management, 3004(May), 1-21. https://doi.org/10.1080/17583004.2018.1476588

WaterAid. (2018). The Water Gap: The state of the World's Water 2018. Retrieved from https://www.wateraidindia.in/sites/g/files/jkxoof336/files/the-water-gap-state-of-water- 
report.pdf

Weitzel, M., Ghosh, J., Peterson, S., \& Pradhan, B. K. (2015). Effects of international climate policy for India: evidence from a national and global CGE model. Environment and Development Economics, 20(4), 516-538. https://doi.org/10.1017/S1355770X14000424

\section{Annex A}

\section{Producing hybrid energy/economy calibration data}

The data hybridization process leading to the development of a hybrid energy/economy dataset consists of 3 main steps described in Gupta et al. (2018). Each of these steps must be adapted to the specifics of the energy systems of the region of analysis. We describe here how we adapted them in the case of India.

We constructed the product $x$ product Input Output (IO) table for 65 products using the supply \& use tables of year 2012-13 by the Indian Central Statistical Office (CSO). To do so, we manipulated the supply \& use matrix with 140 products and 66 sectors (CSO, 2016), based on the 'industry technology' assumption. The data on energy volumes comes from the International Energy Agency (IEA) and the AIM/Enduse model of the Indian Institute of Management Ahmedabad (IIMA). The sources for heterogeneous prices of energy goods are multiple, available from the authors upon request.

The retained level of aggregation of energy and non-energy sectors reflects the specific features of the Indian energy sectors and economy. For instance, we distinguish the cement and aluminium manufacturing sectors because these are the two most energy-intensive sectors in the Indian 
economy. ${ }^{6}$ We dissociate a renewables sector to allow investigating policy objectives of achieving 175 GW renewable energy capacity by the year 2022 (MoEFCC, 2015).

Table $3 \quad$ IMACLIM-IND sectoral breakdown and sector codes

\begin{tabular}{llll}
\hline Energy Sectors (8) & Non- energy sectors (14) \\
\hline COA & Coal & I\&S & Iron \& Steel \\
COK & Coke & CHE & Chemical \\
ONT & Crude oil and non-transport fuels & ALU & Aluminium \\
TRF & Transport fuels & CEM & Cement \\
BIO & Biomass & CON & Construction \\
GAS & Natural gas & TEX & Textile \\
ELE & Electricity & IND & Residual industries \\
REN & Renewable Energy & AGR & Agriculture \\
& & ATR & Air transport \\
& & WTR & Water transport \\
& & ROA & Road transport \\
& & RAI & Rail transport \\
& & HOU & Housing \\
& & SER & Other services \\
\hline
\end{tabular}

The hybridisation process revealed some notable aspects of the Indian energy systems. We report them in the following paragraphs, as well as the statistical treatments that they prompted.

The coal expenses of the electricity sector in the original IO were just $25 \%$ of those obtained by multiplying available price and volume estimates (hereafter the 'volume x price' approach). The official IO documentation reveals that the coal expenses were calculated using data from electricity distribution companies like state electricity boards, departmental commercial undertakings of central and state governments and private electricity companies. Comparatively, the volumes in

${ }^{6}$ The Government of India (GOI) has specified these sectors as the focus areas for meeting the energy efficiency targets under the Perform Achieve Trade (PAT) policy. 
energy balance have been computed using the coal controller's reports, which give the numbers for the output of coal companies going into electricity generation sector. The differences can be attributed to the fact that several companies like Adani, Tata, Reliance and BHEL generate electricity as a secondary output although recorded in sectors other than the electricity sector. ${ }^{7}$ Furthermore, coal companies like Neyveli Lignite corporation (NLC) are also generating electricity. Due to the above factors, we take the expenses obtained from volume $\mathrm{x}$ price rather than those from national accounting 10 table.

Another source of difference in $\mathrm{IO}$ and volume $\mathrm{x}$ price coal expenses is the phenomenon of captive coal mining (introduced in the year 1993) implying that coal is being produced by sectors like power generation, iron \& steel and cement for their own uses. The purpose of the government in allowing private companies into coal mining is to boost the thermal power generation in order to meet the increasing power demand. The percentage of captive coal, currently at a statistically significant $12 \%$, is expected to increase in future (Coal Controller's Organisation, 2015). In order to treat the goods properly, the costs of captive coal mining must be transferred to the coal sector, which is actually the sum of coal mining activities regardless of which sector undertakes the activity. The process involves the following steps: (1) the coal expense of captive mines operators is increased via a price $x$ volume approach using the appropriate coal cost net of profit as the price; (2) all cost elements of the coal mining 'sector' (activity) are increased homothetically in order to rebalance the rise in sales; (3) the costs of the captive mine operators are reduced to exactly compensate the cost increase in the coal mining activity. The broad idea is to transfer the costs of the captive coal mining to the general coal mining activity, and to treat captive coal expenses as any other coal expenses, although

\footnotetext{
${ }^{7}$ The process of shifting from a product $x$ sector (use matrix) to a product $x$ product IO table, using the make matrix, should have re-affected the corresponding share of activity of such firms to the electricity product. This may point at some fault in the process.
} 
priced at net-of-profit costs. Modelling an increase of the share of captive mining in coal expenses can be taken care of by assuming a decrease of the average profit rate of coal mining.

Next is the trading issue that is natural gas being bought by the refined petroleum sector to be sold to consumers. The refined petroleum products expenses of the chemical and electricity sectors from original $I O$ are respectively 2 and 1.5 times the expenses obtained by volume $x$ price approach. Conversely, the natural gas expenses (original IO) of the electricity sector are just $30 \%$ of the expenses from the volume $x$ price approach. Natural gas expenses of the chemical sector (original IO) are $37 \%$ of those obtained from volume $x$ price approach. The refined petroleum products sector appears to play a role of trader, buying a huge amount of natural gas and selling it back to other businesses without consuming it. This implies that the switch from an industry $\mathrm{x}$ industry to a commodity $x$ commodity matrix is not complete, there remains some natural gas sales covered by the refined petroleum products 'sector' of the commodity $x$ commodity matrix. In such a case 10 values can be misleading, hence we decide to use volume $\mathrm{x}$ price data.

Yet another data issue regards household energy consumptions. The bulk of the total energy consumption by households in India is for cooking purposes. Biomass such as firewood, cow-dung and agricultural residues, which households commonly collect themselves (Pachauri, 2007), is the most commonly used fuel for this purpose. We obtain the data on households' expenditure on biomass from the National Sample Survey Office (NSSO), which conducts regular socio-economic survey. Though we have an estimate of the monthly per capita expense on firewood and cow-dung and the percentage of people using these fuels, it is hard to get an estimate for the non-market consumption, i.e. the number of people collecting the biomass themselves. We compare the households' expenses on forestry products specified in 10 table $(1.3 \%$ of total household expenditure) with the firewood and cow-dung ( $1.83 \%$ and $0.16 \%$ of total household expenditure) consumption from NSSO data. The two numbers seem compatible considering the fact that some 
proportion of biomass is non-marketable. Hence, we decide to treat the IOT households' expense on forestry products as the households' expenditure on biomass in our final hybrid matrix.

Another noteworthy issue was the fact that there are significant amounts of non-energy uses of some petroleum products like petroleum coke, lubricants, naphtha and other non-specified oil products in India as opposed to the situation in developed economies. We chose to affect bitumen non-energy uses to the construction sector and petroleum coke non-energy uses to the cement sector. We then distributed the remaining petroleum coke energy consumptions and the other nonenergy uses of petroleum products by proportionally dividing the unaccounted share in volume $x$ price as per the 10 expense across all sectors.

Lastly, considering the increasing prominence of renewables in Indian energy policies and the specific tariffs and incentives for this sector, we decided to add it as a separate sector in our matrix. We calculated expenses on renewables based on the feed-in tariffs provided by the government and the volumes from the energy balance data. We assume that the power sector is the buyer of all renewables outputs. Regarding resources, for lack of data, we assumed the costs into renewables sector proportional to the electricity costs after deduction of fossil fuel costs.

Calibration on the resulting 22-product hybrid 2012 IOT follows the standard procedure of inverting parameters and variables and solving model equations, under constraint of a set of assumptions regarding primary factor prices and non-energy output prices normalisation, without loss of generality.

\section{Sensitivity Analysis}

We conduct sensitivity analysis of our key macroeconomic results to check their variations with changes in exogenous parameters shaping the labour market and foreign trade flows. First, we test for variation in price elasticity for exports. Results show that there is not much variation in real GDP 
but the trade balance contribution to GDP changes significantly. Varying the price elasticity of imports impacts the trade balance ratio, household consumption and the CPI. We find that our results are sensitive to trade elasticities. Lastly, with respect to income elasticities, the macroeconomic results are not impacted by even large variation implying that the model results are insensitive to income elasticities. Our results are not sensitive to real wage elasticity to unemployment since our analysis is based on the specific rule of keeping the unemployment rate constant.

\section{Annex B}

\section{IMACLIM-IND formulary}

The IMACLIM modelling platform has been developed at CIRED, International Centre for Research in Environment and Development located in Paris, since the 1990's. The objective has been to articulate energy and climate policies based on the hybrid energy-economy architecture. Several versions have been developed like the global recursive dynamic model IMACLIM-R World and national versions like the recursive dynamic IMACLIM-R France and the comparative static version IMACLIM-S. Further, national versions for developing countries like Brazil and South Africa have also been developed. On similar lines, we construct the version for India IMACLIM-IND discussed in the sections below. IMACLIM-IND is a computable general equilibrium model (CGEM) designed to assess the medium- to long-term macroeconomic impacts of aggregate price or quantity-based carbon policies, in an accounting framework where economic and physical flows (with a special focus on energy balances) are equilibrated. IMACLIM models depart from the standard neoclassical model in the main feature that their descriptions of the consumers' and producers' trade-offs, and the underlying technical systems, are specifically designed to facilitate calibration on bottom-up expertise in the energy field, with a view to guaranteeing technical realism to their simulations of even large mutations of the energy systems. 
IMACLIM-IND is set up to project the Indian economy for the medium term (2030) and long term (2050). The growth engine of the model results from the combination of exogenous assumptions regarding the demographics of the labour force $L$ and Harrod-neutral technical change $\phi$, i.e. labour productivity gains. Growth develops under constraint of capital accumulation, which follows the simplifying assumption of proportionality to physical investment (Equation 47).

Calibration is the first step of model set-up. It consists of using the model equations to compute parameter values compatible with a set of calibration variables. In the case of IMACLIM models, the calibration dataset is a hybrid Input-Output table with physical labour and energy satellite accounts that involves heavy data treatment (see Annex A above).

IMACLIM-IND operates in a comparative-static framework as a system of simultaneous non-linear equations:

$$
\left\{\begin{array}{c}
f_{1}\left(x_{1}, x_{2} \ldots, x_{n}, y_{1}, y_{2} \ldots, y_{m}\right)=0 \\
f_{2}\left(x_{1}, x_{2} \ldots, x_{n}, y_{1}, y_{2} \ldots, y_{m}\right)=0 \\
\ldots \\
f_{n}\left(x_{1}, x_{2} \ldots, x_{n}, y_{1}, y_{2} \ldots, y_{m}\right)=0
\end{array}\right.
$$

With $x_{i}$ a set of $n$ variables, $y_{i}$ a set of $m$ parameters and $f_{i}$ a set of $n$ functions, for some of them linear, for some of them non-linear, in $x_{i}$. The values of some variables at calibration year constitute a specific subset of parameters, which we systematically note as the variables with a 0 index. The $f_{i}$ functions embody constraints of either an accounting nature or a behavioral nature. The accounting constraints impose themselves on the modeler for the sake of consistency. The behavioral constraints, quite distinctively, convey the modeler's views on economic causalities and correlations. 


\section{Price system}

IMACLIM-IND model differs from the standard CGE model in terms of price and income structural constraints by accounting for non-zero profits via mark-up pricing, considering specific margins for energy goods and by considering sector-specific wages in the model.

\section{Primary factor prices}

IMACLIM-IND calibrates the labour inputs to productions on employment statistics measured in fulltime equivalents. This induces sector-specific average net wages $w_{i}$. The model considers that all $w_{i}$ record the same variation $\delta_{w}$ from their base-year levels $w_{i 0}$ :

$$
w_{i}=\left(1+\delta_{w}\right) w_{i 0}
$$

The endogenous adjustment of $\delta_{w}$ follows a 'wage curve' constraint to the labour market clearing (see section 0 ). In each sector, labour costs $p_{L_{i}}$ are the sum of net wages $w_{i}$ and of labour taxes at $\tau_{L T_{i}}$ rate, which are the social contributions of employers and employees-provident funds in the case of India. The labour tax rates $\tau_{L T_{i}}$ are parameters calibrated at base year. Insurance contribution by agent implies the payroll taxes or contribution to provident fund. The data source for this was the employees' provident fund organization annual report, 2012-13. We consider only the salaried class who contributes to provident fund and not the other status occupations. The informal sector, which occupies the unskilled jobs mostly, does not contribute to provident fund (Gol, 2015).

$$
p_{L_{i}}=\left(1+\tau_{L T_{i}}\right) w_{i}
$$

The average wage across all sectors $w$ is:

$$
w=\frac{\sum_{i=1}^{n} w_{i} \lambda_{i} Y_{i}}{\sum_{i=1}^{n} \lambda_{i} Y_{i}}
$$


The cost of capital write-offs $p_{K}$ is common to all sectors. At base year, its normalisation at 1000 allows calibrating volumes of fixed capital consumption for all sectors based on the money-metric fixed capital consumption of our hybrid IOT. At projection horizon, it is an endogenous variable of IMACLIM-IND, which adjusts to clear the capital write-off capacity (see section 0).

\section{Output prices}

The producer price of good $i, p_{Y i}$, proceeds from the sum of input costs, output taxes at a $\tau_{Y i}$ rate, and a mark-up rate $\pi_{i}$ corresponding to the net operating surplus.

$$
p_{Y i}=\sum_{j=1}^{n} p_{j i} \alpha_{j i}+p_{L i} \lambda_{i}+p_{K} \kappa_{i}+\tau_{Y i} p_{Y i}+\pi_{i} p_{Y i}
$$

Input costs are the products of input prices and input intensities or technical coefficients $\lambda_{i}$ (labour intensity), $\kappa_{i}$ (fixed-capital-consumption intensity) and $\alpha_{j i}$ (intensities in secondary factors including energy intensities). The mark-up rate $\pi_{i}$ is calibrated at base year and held constant in further years.

A Fisher index (geometric mean of the Laspeyres and Paasche indexes) measure the aggregate evolution of output prices:

$$
O P I=\sqrt{\frac{\sum_{i} p_{Y i} Y_{i 0} \sum_{i} p_{Y i} Y_{i}}{\sum_{i} p_{Y i 0} Y_{i 0} \sum_{i} p_{Y i 0} Y_{i}}}
$$

\section{Import and average resource prices}

Import prices $p_{M i}$ are exogenous. 'Other Services' imports act as numéraire of IMACLIM-IND and their price is therefore maintained at base-year value. Energy prices variations from base year reflect AIM/Enduse assumptions.

We consider the imported and domestic energy goods to be homogenous rather than assuming Armington specification as commonly done in CGE models. This is to maintain an explicit account of 
physical volumes, which is one primary component of our approach of modelling. ${ }^{8}$ For the sake of simplicity, we treat non-energy goods similarly to energy goods. The average supply price of good $i$, $p_{S i}$, is therefore the weighted average of the output and import prices of good $i$, with the output and import volumes as weights.

$$
p_{S i}=\frac{p_{Y i} Y_{i}+p_{M i} M_{i}}{Y_{i}+M_{i}}
$$

\section{Intermediate consumption prices}

The price of intermediate goods $p_{i j}$, i.e. the purchaser's price of good $i$ for producing good $j$, is equal to the resource price augmented from trade $\tau_{C M i}$ and transport $\tau_{T M i}$ margins, specific margins $\tau_{S M i j}$ and excise taxes:

$$
p_{i j}=p_{S i}\left(1+\tau_{C M i}+\tau_{T M i}+\tau_{S M i j}\right)+t_{E T i j}
$$

Specific margins embody deviations of purchaser prices from the average output price augmented by the relevant taxes and trade and transport margins. In IMACLIM-IND, where the process of data hybridisation only regards energy goods, they are nil for non-energy goods. For all goods and at all modelled horizons, we keep them at their calibration values.

We also keep all positive trade and transport margins at their calibration values at all modelled horizons. The negative margins, which correspond to those sectors providing the underlying trade and transport services, adjust to warrant the accounting balances:

$$
\sum_{i} \tau_{C M i} p_{S i}\left(\sum_{j=1}^{n} \alpha_{i j} Y_{j}+C_{i}+G_{i}+I_{i}+X_{i}\right)=0
$$

and

\footnotetext{
${ }^{8}$ The Armington specification differentiates the domestic and imported versions of goods. It creates a hybrid of both goods, whose volume does not proceed from the summing of those of the imported and domestic goods.
} 


$$
\sum_{i} \tau_{T M i} p_{S i}\left(\sum_{j=1}^{n} \alpha_{i j} Y_{j}+C_{i}+G_{i}+I_{i}+X_{i}\right)=0
$$

In the case of transport services, which flow from four different sectors, we assume that the four corresponding negative margins adjust according to one single endogenous variation $\delta_{T M}$ :

$$
\forall i \in\{A T R, W T R, R O A, R A I\} \tau_{T M i}=\left(1+\delta_{T M}\right) \tau_{T M i 0}
$$

The lack of statistics prevents differentiating either $\tau_{T M i}$ or $\tau_{C M i}$ by end-use.

\section{Final consumption prices}

The purchaser's prices of good $i$ for households $p_{C i}$, government $p_{G i}$, investment $p_{I i}$ and foreign agents (export price) $p_{X i}$ follow definitions similar to that of intermediate prices, with the difference of the additional value-added tax at rate $\tau_{V A T i}$ for all sales but exports, which do not either bear any excise tax.

$$
\begin{gathered}
p_{C_{i}}=\left(p_{S i}\left(1+\tau_{C M_{i}}+\tau_{T M_{i}}+\tau_{S M C_{i}}\right)+t_{E T C i}\right)\left(1+\tau_{V A T i}\right) \\
p_{G_{i}}=\left(p_{S i}\left(1+\tau_{C M_{i}}+\tau_{T M_{i}}+\tau_{S M G_{i}}\right)+t_{E T G i}\right)\left(1+\tau_{V A T i}\right) \\
p_{I_{i}}=\left(p_{S i}\left(1+\tau_{C M_{i}}+\tau_{T M_{i}}+\tau_{S M I_{i}}\right)+t_{E T I i}\right)\left(1+\tau_{V A T i}\right) \\
p_{X_{i}}=p_{S i}\left(1+\tau_{C M_{i}}+\tau_{T M_{i}}+\tau_{S M X_{i}}\right)
\end{gathered}
$$

Similar to the output price index OPI, a Fisher consumer price index (CPI) measures the aggregate evolution of consumer prices:

$$
C P I=\sqrt{\frac{\sum_{i} p_{C_{i}} C_{i_{0}} \sum_{i} p_{C_{i}} C_{i}}{\sum_{i} p_{C_{i 0}} C_{i_{0}} \sum_{i} p_{C_{i 0}} C_{i}}}
$$




\section{Households}

\section{Income, savings and investment}

The after-tax disposable income of households $R_{H}$ proceeds from primary factor incomes, social transfers, property income and an aggregate of other secondary transfers.

$$
R_{H}=\sum_{i} w_{i} l_{i} Y_{i}+\omega_{K H} G O S+\sum_{i=P, U, T} \rho_{i} N_{i}+\omega_{O T H} G D P-i_{H} D_{H}-\tau_{I T} R_{H}-t_{H} C P I N_{T}
$$

$\sum_{i} w_{i} l_{i} Y_{i}$ is the total net income from labour i.e. the sum of wages obtained from all economic sectors. We obtained labour disaggregation across sectors from the NSS employment survey, except for the 'Renewables' sector, which we obtained from the IRENA (2017) report on 2013 renewable jobs, and for the 'Housing' sector, which we disaggregated from services by assuming homogenous average wage. $\omega_{K H} G O S$ is the share $\omega_{K H}$ of total capital income, or gross operating surplus GOS, directly accruing to households in the form of, mainly, housing rents (imputed or real). Social transfers involve pensions $\rho_{P} N_{P}$, unemployment transfers $\rho_{U} N_{U}$ and other social transfers $\rho_{T} N_{T}$ like support in the form of minimum income given by the government. $\rho_{i}$ stands for per capita transfers and $N_{i}$ for a target population: exogenous pensioned population $N_{P}$, endogenous unemployed population $N_{U}$ or exogenous total population $N_{T}$. Other transfers form a constant $\omega_{\text {OTH }}$ share of GDP calibrated at base year. They include marginal income sources like lottery gains or remittances. Property income is the interest payment on the net debt $D_{H}$ at rate $i_{H}$ resulting from the balance of income from financial assets, bonds or credit, and interest payments on liabilities. Income taxes are paid at rate $\tau_{I T}$ on disposable income $R_{H}$. A per capita $t_{H}$ amount of other direct taxes (housing taxes, land taxes, etc.) is paid as well, which evolves as the consumer price index CPI.

Households savings at rate $\tau_{S}$ adjust to balance investments and savings (see section 0 ). The consumption budget of households is equal to the disposable income net of savings:

$$
R_{C}=\left(1-\tau_{S}\right) R_{H}
$$


The investment effort of households $G F C F_{H}$ is in constant proportion to their disposable income $R_{H}$. We computed the contributions of agents to total gross fixed capital formation using the information on key economic indicators for institutional sectors from Ministry of Statistics and Programme Implementation (MOSPI).

$$
\frac{G F C F_{H}}{R_{H}}=\frac{G F C F_{H 0}}{R_{H 0}}
$$

The net lending or borrowing (NLB) of households $N L B_{H}$ is the difference between their disposable income and their consumption and investment.

$$
N L B_{H}=R_{H}-R_{C}-G F C F_{H}
$$

\section{Consumption choices}

Households' consumptions of energy goods proceed from the coupled AIM/Enduse bottom-up model. The iterative coupling procedure warrants that they are consistent with the evolution of households' income. Non-energy goods are in two sets. One set resorts to elasticities of per capita

consumption $\frac{C_{i}}{N_{T}}$ to real per capita consumption budget:

$$
\forall i \in\{T E X, I N D, A G R, A T R, R A I, R O A, H O U\} C_{i}=C_{i 0} \frac{N_{T}}{N_{T 0}}\left(\frac{R_{C}}{N_{T} O P I} \frac{N_{T 0}}{R_{C 0}}\right)^{\sigma_{C R i}}
$$

For numerical convenience, we use the output price index $O P I$ as a proxy of the CPI deflator to compute real variations of the consumption budget at current prices $R_{C}$.

For lack of better assumption, the remaining set of non-energy goods mobilises constant shares of the consumption budget remainder:

$$
\forall i \in A=\{I \& S, C E M, C H E, A L U, C O N, W T R, S E R\} \frac{p_{C i} C_{i}}{R_{C}-\sum_{j \notin A} p_{C j} C_{j}}=\frac{p_{C i 0} C_{i 0}}{R_{C 0}-\sum_{j \notin A} p_{C j 0} C_{j 0}}
$$


The residual budget shares of I\&S, ALU, CON and WTR are nil. Cement (CEM) mobilises a mere $0.1 \%$ and chemical and petrochemical products (CHE) $5 \%$. The bulk of the residual budget therefore accrues to services (SER).

\section{Firms}

\section{Income and investment}

Similarly to households, firms earn a share $\omega_{K F}$ of capital payments $G O S$ and a share $\omega_{O T F}$ of GDP as other transfers. We calibrate both shares at base year and keep them constant in projections. Firms pay interests at rate $i_{F}$ on their net debt $D_{F}$ as well as corporate taxes at rate $\tau_{C T}$ on their gross operating surplus GOS.

$$
R_{F}=\omega_{K F} G O S+\omega_{O T F} G D P-i_{F} D_{F}-\tau_{C T} G O S
$$

Their investment effort is equal to total investment net of the investment of households and public administrations:

$$
G F C F_{F}=\sum_{i} p_{I i} I_{i}-G F C F_{H}-G F C F_{G}
$$

The fact that total investment is a fixed share of GDP at current prices (see Equation 48) and the investment behaviours of households and public administrations warrants a relatively stable investment effort by firms.

Similar to households as well, the net lending or borrowing of firms is then:

$$
N L B_{F}=R_{F}-G F C F_{F}
$$

Production trade-offs

Coupling with the AIM/Enduse model provides information on the evolution of the energy intensities of all sectors as well as on the capital intensity of a subset of them: all 8 energy sectors, 
heavy industries I\&S, CHE, CEM, ALU and textile TEX. IMACLIM-IND builds on such information, which it treats as exogenous Leontief coefficients. Additionally, it keeps constant at calibration value all technical coefficients that cannot be inferred from AIM (typically non-energy intensities). The coupling process via iteration to convergence warrants that AIM/Enduse energy consumptions and annualised investment costs are consistent with IMACLIM-IND activity drivers.

For the 9 non-energy sectors whose capital intensity is not traced by AIM (CON, IND, AGR, ATR, WTR, ROA, RAI, HOU, SER), IMACLIM-IND considers CES substitutability between capital $K$ and labour $L$, to form a value-added aggregate $K L: K L_{i}=\left(a_{K L i} K_{i}^{\rho_{K L i}}+b_{K L i}\left(\phi_{L} L_{i}\right)^{\rho_{K L i}}\right)^{\frac{1}{\rho_{K L i}}}$, taking account of labour productivity gains $\phi_{L}$. The $\rho_{K L i}$ parameter is in fact a function of $\sigma_{K L i}$ the elasticity of substitution of $K$ to $L$ in sector $i: \rho_{K L i}=\frac{\sigma_{K L i}-1}{\sigma_{K L i}}$. The $a_{K L i}$ and $b_{K L i}$ paramaters are calibrated at base year, they relate to the relative cost shares of $K$ and $L$ for the different activity sectors. At projection year, facing prices $p_{K}$ and $p_{L i}$, cost minimization yields for sectors $i \in\{C O N, I N D, A G R, A T R$, WTR, ROA, RAI, HOU, SER\}:

$$
\begin{gathered}
L_{i}=\frac{1}{\phi_{L}}\left(\frac{b_{K L i} \phi_{L}}{p_{L i}}\right)^{\sigma_{K L i}}\left(a_{K L i}{ }^{\sigma_{K L i}} p_{K}^{1-\sigma_{K L i}}+b_{K L i}{ }^{\sigma_{K L i}}\left(\frac{p_{L i}}{\phi_{L}}\right)^{1-\sigma_{K L i}}\right)^{\frac{-1}{\rho_{K L i}}} K L_{i} \\
K_{i}=\left(\frac{a_{K L i}}{p_{K}}\right)^{\sigma_{K L i}}\left(a_{K L i}{ }^{\sigma_{K L i}} p_{K}^{1-\sigma_{K L i}}+b_{K L i}{ }^{\sigma_{K L i}}\left(\frac{p_{L i}}{\phi_{L}}\right)^{1-\sigma_{K L i}}\right)^{\frac{-1}{\rho_{K L i}}} K L_{i}
\end{gathered}
$$

All secondary factor intensities are exogenous, either taken from AIM (energy intensities) or constant at calibration year value (non-energy intensities). The $K L$ intensity of concerned productions is constant (Leontief assumption):

$$
\forall i \in\{C O N, I N D, A G R, A T R, W T R, R O A, R A I, H O U, S E R\} \frac{K L_{i}}{Y_{i}}=\frac{K L_{i 0}}{Y_{i 0}}
$$




\section{Gross operating surplus}

Gross operating surplus accruing from productive activities is the sum of capital write-offs, profits at mark-up rates $\pi_{i}$ and specific margins $S M$, which are in fact cost differentials between end-uses of each energy sector. From the literature on national statistics, we assume that GOS divides amongst the three agents, corporation, government and households, in ratios of $67 \%, 14 \%$ and $19 \%$ respectively.

$$
G O S=\sum_{i=1}^{n}\left(p_{K} \kappa_{i} Y_{i}+\pi_{i} p_{Y_{i}} Y_{i}\right)+S M
$$

Total specific margins are:

$$
S M=\sum_{i}\left(\sum_{j} \tau_{S M I C i} p_{i} \alpha_{i j} Y_{j}+\tau_{S M C i} p_{i} C_{i}+\tau_{S M G i} p_{i} G_{i}+\tau_{S M X i} p_{i} X_{i}\right)
$$

\section{Public administrations}

\section{Public income}

The gross disposable income of public administrations $R_{G}$ derives from taxes and social security contributions $T$, exogenous $\omega_{K G}$ and $\omega_{O T G}$ shares of the GOS (that of public companies) and GDP, corrected from transfers to households $\sum_{j} \rho_{j} N_{j}$ and interest payments at rate $i_{G}$ on the net public debt $D_{G}$.

$$
R_{G}=T+\omega_{K G} G O S+\omega_{O T G} G D P-\sum_{i=U, P, T} \rho_{i} N_{i}-i_{G} D_{G}
$$

Tax revenue $T$ comprises primary factor and output taxes, the VAT and excise taxes, the income tax and other direct taxes and the corporate tax.

$$
\begin{gathered}
T=\sum_{i=1}^{n} \tau_{L T i} w_{i} l_{i} Y_{i}+\tau_{Y i} p_{Y i} Y_{i}+\frac{\tau_{V A T_{i}}}{1+\tau_{V A T_{i}}}\left(p_{C_{i}} C_{i}+p_{G_{i}} G_{i}+p_{I_{i}} I_{i}\right)+\sum_{i} \sum_{j} t_{E T i j} \alpha_{i j} Y_{j} \\
+t_{E T C i} C_{i}+t_{E T G i} G_{i}+t_{E T I i} I_{i}+\tau_{I T} R_{H}+t_{H} C P I N_{T}+\tau_{C T} \sum_{i} \pi_{i} p_{Y i} Y_{i}
\end{gathered}
$$

Per capita social transfers are in constant proportion to the average wage: 


$$
\forall i \in\{U, P, T\} \frac{\rho_{i}}{w}=\frac{\rho_{i 0}}{w_{0}}
$$

Public expenditures and budget balance

Public expenditures $\sum_{i} p_{G i} G_{i}$ and investment $G F C F_{G}$ are both constant shares of GDP at current prices:

$$
\begin{gathered}
\frac{\sum_{i=1}^{n} p_{G i} G_{i}}{G D P}=\frac{\sum_{i=1}^{n} p_{G i 0} G_{i 0}}{G D P_{0}} \\
\frac{G F C F_{G}}{G F C F_{G 0}}=\frac{G D P}{G D P_{0}}
\end{gathered}
$$

Public expenditures distribute across sectors by assuming homothetical variations from calibration year levels:

$$
G_{i}=\beta_{G} G_{i 0}
$$

The public budget balance or net lending or borrowing of public administrations is:

$$
N L B_{G}=R_{G}-\sum_{i} p_{G i} G_{i}-G F C F_{G}
$$

\section{Rest of the world}

International trade

International trade of energy goods is exogenous from the AIM/Enduse model. For non-energy goods, the competition on international markets depends on the relative prices of goods. The contribution of trade to resources and uses i.e. the ratios of imports $M_{i}$ and exports $X_{i}$ to total supply $Y_{i}+M_{i}$ are elastic to the evolution of domestic $\left(p_{Y_{i}}\right.$ or $\left.p_{X_{i}}\right)$ versus foreign $\left(p_{M_{i}}\right)$ prices.

$$
\begin{aligned}
& \frac{M_{i}}{Y_{i}+M_{i}}=\frac{M_{i_{0}}}{Y_{i_{0}}+M_{i_{0}}}\left(\frac{p_{M_{0}} p_{Y_{i}}}{p_{Y_{0}} p_{M_{i}}}\right)^{\sigma_{M p_{i}}} \\
& \frac{X_{i}}{Y_{i}+M_{i}}=\frac{X_{i_{0}}}{Y_{i_{0}}+M_{i_{0}}}\left(\frac{p_{X_{0}} p_{M_{i}}}{p_{M_{0}} p_{X_{i}}}\right)^{\sigma_{X p_{i}}}
\end{aligned}
$$

The ratio between the domestic and international vectors of prices does not result from a 
trade balance assumption as in standard CGE models. Rather, it is dictated by the assumption of an unemployment rate stabilised at base year level:

$$
u=u_{0}
$$

The purpose of not fixing the trade balance is to allow assessing the transitory impact of low-carbon pathways on trade deficits. Stabilising the unemployment rate requires setting the ratio between domestic and international prices at some specific level, under constraint of the above import and export specifications. The policy interpretation is that of the Indian government manipulating the nominal exchange rate with that objective as target.

\section{Capital flows}

The Rest of the world (ROW) agent balances out trade (by selling imports $\sum_{i} p_{M i} M_{i}$ and buying exports $\left.\sum_{i} p_{X i} X_{i}\right)$, property income and interest payments. Its net lending or borrowing capacity $N L B_{R O W}$ is thus:

$$
N L B_{R O W}=\sum_{i} p_{M i} M_{i}-\sum_{i} p_{X i} X_{i}-\sum_{j=H, F, G} i_{j} D_{j}-\sum_{j=H, F, G} \omega_{O T j} G D P
$$

\section{Market clearings}

\section{Goods markets}

The balance of goods markets is between resources, which comprise domestic production $Y_{i}$ and imports $M_{i}$, and uses, which consists of households' and public consumptions $C_{i}$ and $G_{i}$, immobilisations $I_{i}$ and exports $X_{i}$. For energy goods, the data-hybridization process results in this equation being expressed in million tons-of-oil-equivalent (Mtoe), in_consistency with the 2012 Indian energy balance of the International Energy Agency (IEA). The public consumptions and immobilisations of all energy goods are nil, by national accounting convention for the former and by definition for the latter. 


$$
Y_{i}+M_{i}=\sum_{j=1}^{n} \alpha_{i j} Y_{j}+C_{i}+G_{i}+I_{i}+X_{i}
$$

\section{Labour market}

Total labour demand from sector $i$ is:

$$
L_{i}=\lambda_{i} Y_{i}
$$

Labour market clearing requires that labour demand and unemployment balance out labour supply from households. One of the key structural assumptions of IMACLIM-IND is indeed to consider equilibrium unemployment $u$. The labour supply of households or labour endowment $L$ is an exogenous parameter computed from International Labour Organisation (ILO) 2018 estimates until 2021 and considering the 2020 ratio of labour to working age (20 to 69) population (UN, 2015) from 2021 on.

$$
\sum_{i=1}^{22} L_{i}=(1-u) L
$$

The unemployed population $N_{U}$ is:

$$
N_{U}=u L
$$

A wage curve describes the correlation between the unemployment rate and the average wage (Blanchflower and Oswald, 2005). The purchasing power of wages-the average wage at current prices $w$ deflated by the consumer price index $C P I-$ is elastic to unemployment variations $\frac{u}{u_{0}}$ with $\sigma_{w u}$ elasticity, around a trend defined by labour productivity gains $\phi_{L}$ :

$$
\frac{w}{C P I}=\phi_{L} w_{0}\left(\frac{u}{u_{0}}\right)^{\sigma_{w u}}
$$

\section{Capital markets}

Total capital write-offs from sector $i$ are:

$$
K_{i}=\kappa_{i} Y_{i}
$$


Considering current implementations in single time steps from 2012 to 2030 and 2050, version 1.0 of IMACLIM-IND simplifies capital accumulation by assuming that total fixed capital consumption grows proportionally to investment flows:

$$
\sum_{i=1}^{22} K_{i}=\beta_{I} \sum_{i=1}^{22} K_{i 0}
$$

The cost of capital write-offs $p_{K}$ adjusts to constrain them to this target level (see below).

Investment and savings

Rather than considering fixed domestic and foreign savings and closing on investment (neoclassical closure rule of the standard CGE model), IMACLIM-IND considers a fixed investment effort ('Johansen closure' following Sen, 1963), flexible foreign savings-induced by the exchange rate adjustments allowing to maintain the unemployment level (see Equation 39)-and closes on domestic savings by adjustment of households' savings rate $\tau_{S}$. Investment is an exogenous GDP share:

$$
\sum_{i=1}^{22} p_{I i} I_{i}=s_{I} G D P
$$

The investment supply of households is a fixed share of their income and that of public administrations a fixed share of GDP. The investment supply of firms adjusts to match investment demand (see Equation 23 above).

Similar to public expenditures, the investment effort distributes across sectors by assuming homothetical variations from calibration values i.e. constant composition of the homogenous (across sectors) investment good:

$$
I_{i}=\beta_{I} I_{i 0}
$$

\section{GDP}

GDP is the sum of final expenditures: 


$$
G D P=\sum_{i=1}^{22} p_{C_{i}} C_{i}+p_{G_{i}} G_{i}+p_{I_{i}} I_{i}+p_{X_{i}} X_{i}-p_{M_{i}} M_{i}
$$

\section{Net debts of agents}

Depending on its sign at calibration year and at the projection horizon, the NLB of agents accumulates into debt or credit. The assumption is that agents see their NLB net of interest payments or Primary Balance evolve linearly over the $y$ years between the calibration year and the projection year. Interests accrue at agent-specific rate $i_{j}, j \in\{H, F, G\}$, while monetary inflation at rate $\tau_{I M}$ erodes the real value of the calibration-year net debt $D_{j 0}$. By recursion and using known sums of terms of geometric suites, the net debt at projection horizon is therefore, for $j \in\{H, F, G\}$ :

$$
D_{j}=\left(\frac{1+i_{j}}{1+\tau_{I M}}\right)^{y} D_{j 0}-A_{D j}\left(P B_{j 0}-(y-1) \frac{P B_{j}-P B_{j 0}}{y}\right)+B_{D j} \frac{P B_{j}-P B_{j 0}}{y}
$$

with

$$
\begin{gathered}
P B_{j}=N L B_{j}+i_{j} D_{j} \\
A_{D j}=\frac{1-\left(1+i_{j} / 1+\tau_{I M}\right)^{y}}{1-{ }^{1+i_{j}} / 1+\tau_{I M}} \\
B_{D j}=\frac{\left(1+\tau_{I M}\right)^{y}\left(1+i_{j}\right)-y\left(1+\tau_{I M}\right)\left(1+i_{j}\right)^{y}+(y-1)\left(1+i_{j}\right)^{y+1}}{\left(\tau_{I M}+i_{j}\right)^{2}\left(1+\tau_{I M}\right)^{y-1}}
\end{gathered}
$$

The net debt of foreign agents $D_{R O W}$ balances out the net domestic debts:

$$
D_{R O W}=-\sum_{j=H, F, G} D_{j}
$$

\section{IMACLIM-IND notations}

IMACLIM-IND counts 886 equations, taking account of the fact that:

- Equations (3), (5), (8), (9), (15), (16), (17), (18), (19), (22), (23), (24), (28), (29), (30), (31), (33), (34), (36), (39), (40), (43), (44), (45), (47), (48), (50) and (55) count once each: 28 equations, 
- Equations (32), (51), (52), (53), (54) count 3 times each (one equation per type of public transfer or per type of domestic agent): 15 equations,

- Equation (10) counts 4 times (one equation per transport sector): 4 equations,

- Equations (20) and (21) count 7 times each (7 income-elastic non-energy goods, 7 other nonenergy goods): 14 equations.

- Equations (25), (26) and (27) count 9 times each (9 productions with endogenous $K$ versus $L$ trade-off): 27 equations.

- Equations (37) and (38) count 14 times each (one equation per non-energy good): 28 equations.

- Equations (1), (2), (4), (6), (11), (12), (13), (14), (35), (41), (42), (46) and (49) count 22 times each (one equation per sector): 286 equations.

- Equation (7) counts 484 times (on equation per sector at power 2): 484 equations.

The following table identifies the 886 variables (Var. count of last-but-one column) matching this number of equations. It also lists all parameters of the model, which for most of them are calibrated at base-year level on our hybrid dataset, for some other stem from other outside sources. 


\begin{tabular}{|c|c|c|c|}
\hline Notation & Description & Var. & Par. \\
\hline$A_{D j}$ & $\begin{array}{l}\text { Element of net debt computation (to ease exposition), } j \in\{H, F, G\} \text { (households, } \\
\text { firms, public administrations). }\end{array}$ & 3 & 0 \\
\hline$B_{D j}$ & $\begin{array}{l}\text { Element of net debt computation (to ease exposition), } j \in\{H, F, G\} \text { (households, } \\
\text { firms, public administrations). }\end{array}$ & 3 & 0 \\
\hline$C_{i}$ & Final consumption of good $i$ by households. & 14 & 8 \\
\hline$D_{j}$ & $\begin{array}{l}\text { Net debt of agent } j \in\{H, F, G, R O W\} \text { (households, firms, public administrations, } \\
\text { foreign agents). }\end{array}$ & 4 & 0 \\
\hline$G F C F_{j}$ & $\begin{array}{l}\text { Gross fixed capital formation of agent } j \in\{H, F, G\} \text { (households, firms, public } \\
\text { administrations). }\end{array}$ & 3 & 0 \\
\hline$G_{i}$ & Final public consumption of good $i$. & 22 & 0 \\
\hline$I_{i}$ & Final consumption of good $i$ for the investment. & 22 & 0 \\
\hline$K_{i}$ & Total capital write-offs in sector $i$ & 22 & 0 \\
\hline$L_{i}$ & Total labour demand from sector $i$ & 22 & 0 \\
\hline$K L_{i}$ & $\begin{array}{l}\text { Value-added intensity of the production of good } i \in \\
\{C O N, I N D, A G R, A T R, W T R, R O A, R A I, H O U, S E R\}\end{array}$ & 9 & 0 \\
\hline$M_{i}$ & $\begin{array}{l}\text { Imports of good } i \text {. Imports of Coke and Transport fuels are exogenous, from the } \\
\text { Aim/Enduse model. Imports of Biomass, Electricity and Renewable Energy are } \\
\text { exogenously set at } 0 \text {. }\end{array}$ & 17 & 5 \\
\hline$N L B_{j}$ & $\begin{array}{l}\text { Net lending or borrowing of agent } j \in\{H, F, G, R O W\} \text { (households, firms, public } \\
\text { administrations, foreign agents). }\end{array}$ & 4 & 0 \\
\hline$N_{P}$ & Pensioned population & 0 & 1 \\
\hline$N_{T}$ & Total population & 0 & 1 \\
\hline$N_{U}$ & Unemployed population & 1 & 0 \\
\hline$P B_{j}$ & $\begin{array}{l}\text { Primary balance (net lending or borrowing excluding interest payments) of agent } \\
j \in\{H, F, G\} \text { (households, firms, public administrations). }\end{array}$ & 3 & 0 \\
\hline$R_{C}$ & Consumption budget of households & 1 & 0 \\
\hline$R_{j}$ & $\begin{array}{l}\text { Gross disposable income of agent } j \in\{H, F, G\} \text { (households, firms, public } \\
\text { administrations). }\end{array}$ & 3 & 0 \\
\hline$X_{i}$ & $\begin{array}{l}\text { Export of good } i \text {. Exports of } 8 \text { energy goods are exogenous from AIM/Enduse } \\
\text { model. }\end{array}$ & 14 & 8 \\
\hline$Y_{i}$ & $\begin{array}{l}\text { Domestic output of good } i \text {. Ouput of Coal, Oil and non-transport fuels and Natural } \\
\text { gas are exogenous from AIM/Enduse model. }\end{array}$ & 19 & 3 \\
\hline$a_{K L i}$ & $\begin{array}{l}\text { Parameter of substitution of } K \text { to } L \text { in good } i \text { production, } \\
i \in\{C O N, I N D, A G R, A T R, W T R, R O A, R A I, H O U, S E R\} .\end{array}$ & 0 & 9 \\
\hline$b_{K L i}$ & $\begin{array}{l}\text { Parameter of substitution of } K \text { to } L \text { in good } i \text { production, } \\
i \in\{C O N, I N D, A G R, A T R, W T R, R O A, R A I, H O U, S E R\} .\end{array}$ & 0 & 9 \\
\hline$i_{j}$ & Effective interest rate on the net debt of agent $j \in\{H, F, G\}$ & 0 & 3 \\
\hline$p_{C i}$ & Price of good $i$ for households & 22 & 0 \\
\hline$p_{G i}$ & Public price of good $i$ & 22 & 0 \\
\hline$p_{I i}$ & Investment price of good $i$ & 22 & 0 \\
\hline$p_{K}$ & Cost of capital write-offs. & 1 & 0 \\
\hline$p_{L i}$ & Cost of labour input in the production of good $i$ & 22 & 0 \\
\hline$p_{M i}$ & Import price of good $i$ & 0 & 22 \\
\hline$p_{S i}$ & Average price of good $i$ supply (output and imports) & 22 & 0 \\
\hline
\end{tabular}




\begin{tabular}{|c|c|c|c|}
\hline$p_{X i}$ & Export price of good $i$ & 22 & 0 \\
\hline$p_{Y i}$ & Output price of good $i$ & 22 & 0 \\
\hline$p_{i j}$ & Price of good $i$ for the production of good $j$ & 484 & 0 \\
\hline$s_{I}$ & Investment effort as a share of GDP at current prices. & 0 & 1 \\
\hline$t_{E T C i}$ & Excise taxes per unit of household consumption of good $i$. & 0 & 22 \\
\hline$t_{E T G i}$ & Excise taxes per unit of public consumption of good $i$. & 0 & 22 \\
\hline$t_{\text {ETIi }}$ & Excise taxes per unit of good $i$ immobilisation. & 0 & 22 \\
\hline$t_{E T i j}$ & Excise taxes per good $i$ consumption in good $j$ production. & 0 & 484 \\
\hline$t_{H}$ & Per capita direct tax of households at calibration year prices. & 0 & 1 \\
\hline$w_{i}$ & Average net wage in the production of good $i$ & 22 & 0 \\
\hline$\alpha_{i j}$ & Technical coefficient, good $i$ intensity of good $j$ & 0 & 484 \\
\hline$\beta_{G}$ & $\begin{array}{l}\text { Scaling factor of public consumptions between calibration-year and projection } \\
\text { year. }\end{array}$ & 1 & 0 \\
\hline$\beta_{I}$ & Scaling factor of immobilisations between calibration-year and projection year. & 1 & 0 \\
\hline$\delta_{T M}$ & $\begin{array}{l}\text { Variation of transport margin rates on transport sectors sales from calibration } \\
\text { year to projection year. }\end{array}$ & 1 & 0 \\
\hline$\delta_{w}$ & $\begin{array}{l}\text { Variation of wages relative to the price of the numéraire (Oter services imports) } \\
\text { from calibration year to projection year. }\end{array}$ & 1 & 0 \\
\hline$\kappa_{i}$ & Technical coefficient, capital (write-off) intensity of good $i$. & 9 & 13 \\
\hline$\lambda_{i}$ & Technical coefficient, labour intensity of good $i$. & 9 & 13 \\
\hline$\pi_{i}$ & Rate of net operating surplus (mark-up rate) in the production of good $i$. & 0 & 22 \\
\hline$\rho_{K L i}$ & $\begin{array}{l}\text { Parameter of substitution of } K \text { to } L \text { in good } i \text { production, } \\
i \in\{C O N, I N D, A G R, A T R, W T R, R O A, R A I, H O U, S E R\} \text {. }\end{array}$ & 0 & 9 \\
\hline$\rho_{P}$ & Average per capita pensions benefitting to the retired population. & 1 & 0 \\
\hline$\rho_{T}$ & $\begin{array}{l}\text { Average per capita transfers benefitting to households outside unemployment } \\
\text { benefits and pensions }\end{array}$ & 1 & 0 \\
\hline$\rho_{U}$ & Average per capita unemployment benefits accruing to the unemployed. & 1 & 0 \\
\hline$\sigma_{C R i}$ & $\begin{array}{l}\text { Income-elasticity of households' consumption of good } i \in \\
\{T E X, I N D, A G R, A T R, R A I, R O A, H O U\}\end{array}$ & 0 & 7 \\
\hline$\sigma_{K L i}$ & $\begin{array}{l}\text { Elasticity of substitution of } K \text { to } L \text { in good } i \text { production, } \\
i \in\{C O N, I N D, A G R, A T R, W T R, R O A, R A I, H O U, S E R\}\end{array}$ & 0 & 9 \\
\hline$\sigma_{M p i}$ & $\begin{array}{l}\text { Elasticity to the ratio of output to import prices of the contribution of imports to } \\
\text { total good } i \text { supply. }\end{array}$ & 0 & 14 \\
\hline$\sigma_{X p i}$ & $\begin{array}{l}\text { Elasticity to the ratio of import to export prices of the share of exports into total } \\
\text { good } i \text { uses. }\end{array}$ & 0 & 14 \\
\hline$\sigma_{w u}$ & Elasticity of the purchasing power of wages to the unemployment level. & 0 & 1 \\
\hline$\tau_{C M i}$ & Trade margin on the sales of good $i$. & 1 & 21 \\
\hline$\tau_{C T}$ & Corporate tax rate on firms' net operating surplus. & 0 & 1 \\
\hline$\tau_{I M}$ & $\begin{array}{l}\text { Average annual monetary inflation rate between the calibration year and the } \\
\text { projection horizon. }\end{array}$ & 0 & 1 \\
\hline$\tau_{I T}$ & Income tax rate on households' gross disposable income. & 0 & 1 \\
\hline$\tau_{L T i}$ & Social contribution (labour tax) rate applicable to wages in sector $i$ & 0 & 22 \\
\hline$\tau_{S}$ & Households' rate of savings of their gross disposable income. & 1 & 0 \\
\hline$\tau_{S M C i}$ & Specific margin on households' consumption of good $i$. & 0 & 22 \\
\hline
\end{tabular}




\begin{tabular}{|c|c|c|c|}
\hline$\tau_{S M G i}$ & Specific margin on public consumption of good $i$. & 0 & 22 \\
\hline$\tau_{S M X i}$ & Specific margin on good $i$ exports. & 0 & 22 \\
\hline$\tau_{S M i j}$ & Specific margin on good $i$ consumption in good $j$ production. & 0 & 484 \\
\hline$\tau_{T M i}$ & Transport margin on the sales of good $i$ & 4 & 18 \\
\hline$\tau_{V A T i}$ & VAT rate applying to the final consumption of good $i$. & 0 & 22 \\
\hline$\tau_{Y i}$ & Output tax rate on the production of good $i$. & 0 & 22 \\
\hline$\omega_{K j}$ & $\begin{array}{l}\text { Share of capital income accruing to agent } j \in\{H, F, G\} \text { (households, firms, public } \\
\text { administrations). }\end{array}$ & 0 & 3 \\
\hline$\omega_{\text {OTj }}$ & $\begin{array}{l}\text { Share of not-elsewhere accounted transfers accruing to agent } j \in\{H, F, G\} \\
\text { (households, firms, public administrations). }\end{array}$ & 0 & 3 \\
\hline$\phi_{L}$ & $\begin{array}{l}\text { Scaling factor of labour productivity between calibration year and projection } \\
\text { horizon. }\end{array}$ & 0 & 1 \\
\hline$C P I$ & Consumer price index. & 1 & 0 \\
\hline$G D P$ & Gross domestic product. & 1 & 0 \\
\hline GOS & Gross operating surplus & 1 & 0 \\
\hline$L$ & Total active population (labour supply) in full-time equivalents & 0 & 1 \\
\hline$O P I$ & Output price index. & 1 & 0 \\
\hline$S M$ & Sum across goods and uses of agent-specific margins & 1 & 0 \\
\hline$T$ & Total taxes and social contributions. & 1 & 0 \\
\hline$u$ & Unemployment rate & 1 & 0 \\
\hline$w$ & Average net wage across all sectors & 1 & 0 \\
\hline$y$ & Number of years from the calibration year to the projection horizon. & 0 & 1 \\
\hline
\end{tabular}

\section{Annex C}

Table C1 Assumptions on advanced targets for 2-degree scenario implementation

\begin{tabular}{llll}
\hline Sector/Field & Subfield & Advance targets & References \\
\hline Clean energy & Wind & $77 \mathrm{GW}$ by 2022 & \\
& Solar & $128 \mathrm{GW}$ by 2022 & The Economic Times \\
& Biomass & $13 \mathrm{GW}$ by 2022 & $(2018)$ \\
& Small hydro & $6.4 \mathrm{GW}$ by 2022 & Department of Atomic \\
& Nuclear & $63 \mathrm{GW}$ by 2032 & Energy (2015) \\
& & $\begin{array}{l}\text { About } 144 \text { old thermal stations have } \\
\text { been assigned mandatory targets for } \\
\text { improving energy efficiency; early } \\
\text { retirement of 23 GW of coal-based } \\
\text { clean coal }\end{array}$ & $\begin{array}{l}\text { Central Electricity } \\
\text { calthority (2018) }\end{array}$ \\
& Old plants & & \\
\hline
\end{tabular}




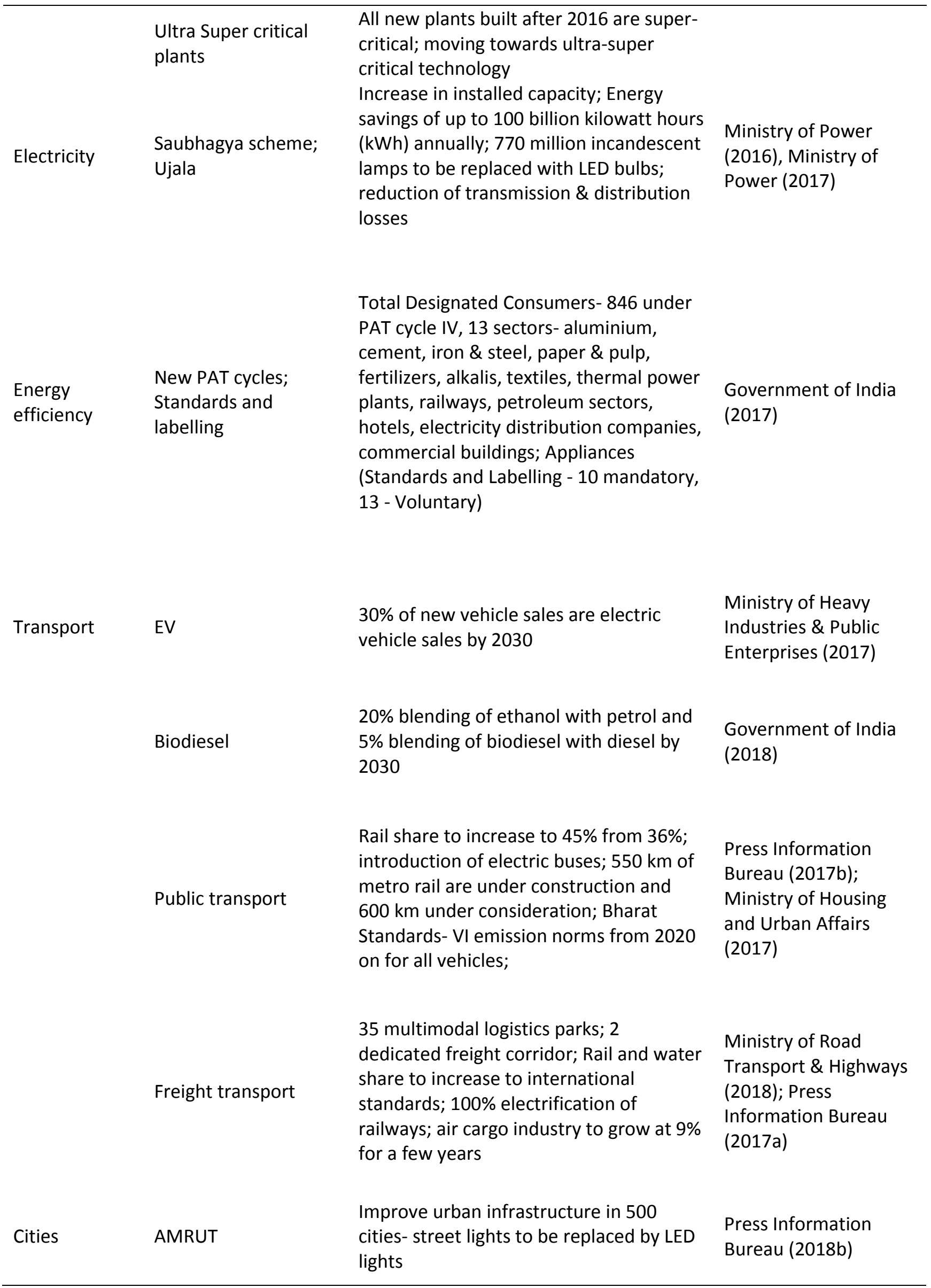


Clean cooking fuel 